PACHECOBARROS, Wellington, A propriedade agrária e seunovo conceito jurídico constitucional,Porto Alegre, RevistaAjuris, $n^{\circ} 32$

PENTEADO, Mauro Rodrigues, "Exposição Justificativa da Proposta de Modificação do Título VIII, Livro I, Parte Especial, do Projeto de Código Civil (PLC no 118/84) que dispõe sobre os Títulos de Crédito", in O Projeto de Código Civil no Senado, Tomo II, Brasília, Senado Federal, 1998.

PERLINGIERI, Pietro,II Diritto Civile nella legalità costituzionale", Nápoles, Edizione Scientifiche Italiane, 1991

PONTES DE MIRANDA, F.C, Fontes e Evolução do Direito Civil Brasileiro, Rio de Janeiro, Forense, 1981

PONTES DE MIRANDA, Tratado de Direito Privado, Tomo II, Rio de Janeiro, Borsói,

PONTESDEMIRANDATratadode Direito Privado, T.26, Ed. Borsói, Riode Janeiro, 1959.

PORTO, Sérgio José A Responsabilidade Civil por Difamação no Direito Inglês, Ed. Sergio Fabris, Porto Alegre, 1995.

PROUDHON. Qu'est-ce que la propriété, in Oeuvres Choisies. Paris, Gallimard, 1967.

RAISER, Ludwig, "Il futuro del Diritto Privato", in: Il Compito del Diritto Privato, trad. Italiana de Marta Graziadei, Milão, Giuffrè, 1990.

REALE, Miguel, Memórias - vol. 2 -a Balança e a Espada, São Paulo, Saraiva, 1987, p. 221

REALE, Miguel, O Projeto de Código Civil Situação atual e seus problemas fundamentais, São Paulo, Saraiva, 1986.

REALE, Miguel, O Projeto do Novo Código Civil-situação após a aprovação pelo Senado Federal, São Paulo, Saraiva, 2000.

REALE Fundamentos do Direito, São Paulo, Revista dos Tribunais, 3a. edição, 1998.

REALE, Miguel, Pluralismo e Liberdade ,Rio de Janeiro, Expressão e Cultura, $2^{a}$ edição, 1998.
REALE, Miguel, Código Civil-Anteprojetos, vol. 5, Tomo 1, Senado Federal, Subsecretaria de Edições Técnicas, Brasília, 1989.

REALE, Miguel, O Direito como Experiência, São Paulo, Saraiva, 1968.

REALE, Miguel, Fontes e Modelos do Direitopara um novo paradigma hermenêutico,São Paulo, Saraiva, 1994.

RIBEIRO LOPES, Maurício, Dignidade da Pes soa Humana, in Revista dos Tribunais 758 106-117.

RODOTÀ, Stefano, El terrible derechoEstudios sobre la propiedad privada, Madri, Civitas, 1986.

ROPPO, Enzo, O Contrato, trad., de Ana Coimbra e M. Januário Gomes, Ed. Almedina, Coimbra, 1988

SENADOFEDERAL, O Projeto de Código Civil no Senado, Tomo II, Brasília, Senado Federal, 1998.

SILVA PEREIRA, Caio Mario, Instituições de Direito Civil, v. $1, \mathrm{n}^{\circ} 16$

SILVA PEREIRA, Caio Mario, Lesão nos Contratos, Rio de Janeiro, Forense, $4^{\text {a }}$ Edição, 1993.

TALLON, Denis, "L'évolution des idées en matière de contrat: survol comparatif", in Droits, 12, 1990.

VARELA, Laura Beck, "A Tutela da Posse entre abstração e autonomia: uma abordagem histórica," in A Reconstrução do Direito Privado - reflexos dos princípios e garan tias fundamentais no Direito Privado, MARTINS-COSTA, Judith (org)., no prelo.

ZAVASKI, Teori, "A tutela da posse na Constituição e no Projeto do novo Código Civil", in MARTINS-COSTA, Judith, A Reconstrução do Direito Privado - reflexos dos princípios e garantias fundamentais no $\mathrm{Di}$ reito Privado, no prelo.

\section{Repudiando Montesquieu? A Expansão e a Legitimidade da "Justiça Constitucional" *}

\author{
Mauro Capelletti \\ (Tradução de Fernando Sá - advogado em Porto Alegre)**
}

se ela existe ou não, em algum ponto final, em alguma abrangente permanência, um Absoluto que proporcione uma trégua, sentido e luz a todo este comovente, batalhado e fugaz fenômeno que é a vida humana.

Tenho a honra de estar hoje com vocês, que "a justiça humana" pode fazer é olucionar, ou tentar solucionar, problemas concretos da vida individual e social: promulgar e impor normas, criar instituições, traçar processos, tudo com um objetivo em mente dirimir problemas reais. Mas os problemas humanos mudam continuamente, assim como as normas, os processos e as instituições. A justiça humana está mudando a idéia de Justiça, em um tributo de respeito e gratidão ao Papa João XXIII. Sua visão de fé no Absoluto não diminuiu seu profundo compromisso e ardor pela mudança. A justiça humana nunca cessou de ser a sua preocupação. Suas duas principais Encíclicas, Mater et Magistra (1961) e Pacem in Terris $(1963)^{1}$ representam um formidáve esforço na tentativa de traçar as linhas básicas

* Nota do tradutor: esta tradução resulta de um repto a mim lançado pelo amigo e professor Carlos Alberto Alvaro de Oliveira em suas aulas no mestrado da Faculdade de Direito da UFRGS. Aceito o desafio, teve ainda o mestre a dedicação [no que pese a tremenda carga de trabalho que enfrenta, como Magistrado consciente responsável, no Tribunal de Justiça do Estado do Rio Grande do Sul] de revisar e conformar à linguagem técnica do texto certos conceitos do autor.

* Copyright Mauro Capelletti. Esta é uma versão brevemente revista de um artigo originariamente publicado em 35 Catholic University Law Review 10001-1032 (1985). É um texto anotado da 20 Conferência Anual do Papa João XXIII proferida no dia 25 de abril de 1985 na Universidade Católica Americana em Washington, D.C. Fo João XXII pronstion

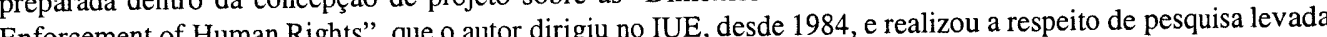
Enforcement of miro pelo autor, denominado "Access to Justice Project" a efeito no IEU em dois projes prosts. I-IV, Milão \& Alphen (1976-79) (resultados publicados in M. Castice and the Welfare aan den Rijn, Giuffre \& Sijhoff \& Nordhoff, 1978-79) e M. Cappelltion State, Alphen aan den Rijn \& Bruxelles, Stihhoff \& Bruylant, in Light of the American Federal Experience" (1979-85) (resultados publicados in M. Cappelletti, M. Seccombe \& J. Weiler, gen., eds., Integration Through Law: Europe and the American Federal Exper VI, Berlin \& New York, Walter de Cruyter, 1985-...

${ }^{1}$ A versão inglesa comentada pode ser encontrada in The Encyclicas and Other Messages of John XXIII, editada por Staff of the Pope Speaks Magazine, Washington, D.C., TPS Press, 1964 
para a solução do que seja talvez o mais desafiador dos problemas da vida em nossa época: o desafio da opressão, da pobreza e da guerra; os problemas da liberdade e da dignidade humanas, da justiça social e da coexistência pacífica dos indivíduos e dos povos; problemas cuja solução deveriam unir, como ele afirmou, todos os homens de boa vontade, pouco importando a raça, a nacionalidade e a fé. Ele nos deu, assim, a base para esboçar uma filosofia de vida para os indivíduos e as nações de nossa época.

Em suas raízes pode-se dizer que sua doutrina era relevante para todos os tempos, pois cada época sofre opressão, injustiça social, violência e guerra. Mas, num sentido mais profundo, a sua doutrina tinha o significado de uma filosofia essencialmente do e para nosso tempo. Essa foi a lição tirada dos tremendos desafios do nosso século, o qual, embora alardeando os mais nobres ideais de liberdade individual e de dignidade humana, caracterizouse justamente como sendo a época dos mais terríveis sistemas de opressão dos indivíduos, grupos e povos, como o foram o holocausto e o tentado genocídio de populações e de nações inteiras. Este nosso século, embora tenha testemunhado o mais impressionante crescimento de riqueza material e de genuína possibilidade de criar novas riquezas e bem estar, foi e vem sendo flagelado pela miséria nascente e pela fome maciça. O mundo, reduzindo-se no seu tamanho, pede, e até mesmo clama, por união e paz. Todavia, esta tem sido a era das mais terríveis guerras mundiais e de uma impendente ameaça de um terceiro e derradeiro conflito; o dilúvio universal; o fim, possivelmente, da humanidade.

É tempo, para todos nós, de nos preocuparmos com o fundamental. Se alguns episódios, relativamente limitados, como, por exemplo, o escândalo de Watergate, têm feito advogados e professores americanos de Direito lembrar que existe um problema de moralidade no Direito, na profissão e na formação jurídica, e se o Vietnam, assim como também o Iraque e o Chile e o Afeganistão, e muitos outros, fizeram com que homens e mulheres lembrassem ainda mais - felizmente atrás da cortina de ferro também - que existe um problema de moralidade na política e no modo em que nosso mundo em perigo é conduzido, é tempo, então, para todos nós, de nos preocuparmos em encontrar solução adequada para as mais importante questões que nos assolam - os problemas de sobrevivência em nossa época. Os problemas de buscar a liberdade, a justiça e a paz são novos, pela forma como assumiram afinal uma dimensão sem precedentes em nosso tempo: uma dimensão que, se as soluções adequadas não forem encontradas, pode eventualmente significar o fim do milênio da civilização.

Seja-me permitido, então, usar este privilegiado forum, para fazer um breve interrogatório em busca da resposta específica que a nossa época tem tentado dar àqueles problemas maiores da sobrevivência especialmente para um deles - o problema da opressão política. Em um nível pessoal, gostaria de acrescentar que me é particularmente gratificante falar a respeito deste tópico, hoje 25 de abril, dia da liberação da Itália, o quadragésimo aniversário da libertação de minha pátria, de um terrível sistema de opressão política que levou à mais trágica de todas as guerras. Minha busca focar-se-á, na Europa mas não se limitará a ela; e, obviamente, será a indagação de um advogado, uma vez que procurarei ordenar algumas das mais significativas normas legais, instituições e processos que proporcionam, em minha opinião, respostas objetivas ou potenciais ao mais dramático desafio de nosso tempo. Outros, naturalmente, podem propor diferentes respostas para este desafio - ou, como preferiria pensar, diferentes facetas à mesma resposta - oferecendo, por exemplo, visualizações econômicas, mais do que legais, como estou eu, aqui e agora, mais diretamente preocupado.

\section{O Significado de "Justiça Constitucional"}

A principal resposta em termos de justiça legal, ao problema da opressão, pode ser expressa por uma formula largamente usada hoje em dia na Europa: Justiça Constitucional. É comum dizer-se que o poder governamental encontra-se limitado por uma norm constitucional, e que os procedimentos tenhan sido concebidos e as instituições criadas para implementar tal limitação.

Na verdade, as formas de opressão que caracterizam nossa época são várias e muito complexas. Por exemplo, o poder não governamental - como o poder de grupo organizados, as corporações econômicas, os sindicatos, as associações, e os partidos políticos - ocasionalmente provou não se menos perigoso e opressivo, não menos invaso da privacidade e da liberdade dos indivíduos, do que o poder oficial do Estado. Mesmo os fantásticos e esplêndidos desenvolvimentos tecnológicos constituem-se numa ameaça potencial, pois os instrumentos de intromissão tornaram-se cada vez mais disponíveis para uso opressivo imediato. E, na verdade, nunca talvez tão agudamente quanto nos dias de hoje o indivíduo sentiu a opressão da "solidão dentro da multidão"; o sentimento de que nossa voz como a paráfrase bíblica, clamans in deserto; sentimento de alienação, que constitui uma das mais básicas doenças psicológicas do homem moderno.

Ademais, o perigo que provou ser o mais temido de nosso século é, sem dúvida, o poder organizado - o Estado e a sua multiplicidade de órgãos e agências, sua proliferação central e local. Os casos, para mencionar apenas os mais clamorosos, da Alemanha Nazista, da Itália fascista e da Rússia de Stalin, nunca passarão sem nos terem ensinado a mais importante lição: quando o poder político não sofre controle, mesmo os instrumentos da nova tecnologia, da comunicação de massa, da assim chamada "educação popular", tudo pode perverter-se numa grande máquina corruptora. A corrupção das mentes é obtida através da desinformação maciça e da proibição de toda crítica. Lembro uma das mais infames leis, discutidas alguns anos atrás pelos professores Hart e Fuller ${ }^{2}$, num dos mais citados debates sobre o direito e a moral. A lei alemã, de 1944, permitia que um homem, denunciado por sua mulher, fosse condenado à pena capital, pelo "crime" de criticar Hitler ${ }^{3}$, quando em licença militar, em sua casa. O que pode emergir de um governo sem controle, como a triste história recente nos revela, é uma distorção, até mesmo para o mais prosaico sentido de justiça. Daí, a intolerância e o fanatismo e, eventualmente, a aceitação, e até mesmo o chamamento à violência e à guerra A justiça constitucional, acredito, é na verdade uma das mais importantes e promissoras respostas que um crescente número de nações tem procurado dar a esse problema da opressão governamental. Como já mencionado, o que está implícito na justiça constitucional é a noção de um novo 4 tipo de normas constitucionais,

${ }^{2} \mathrm{H}$. L A HART "Positivism and Fidelity to Law - A Reply to Professor Hart". Ibidem, 630-672.

${ }^{2} \mathrm{H}$. L. A HART, "Positivism and Fidelity to Law - A Repl

3 HART, ob., cit., 618-619; FULLER, ob. cit., 654-655.
${ }^{4}$ Para alguns precedentes históricos, entretanto, vide, v.g., M. CAPPELLETTI e J. C. ADAMS, "Judicial Review ${ }^{4}$ Para alguns precedentes históricos, entretanto, vide, v.g., M. CAPPELLETT1 e J. 24 (1966); M. CAPPELLETTI, of Legislation: European Antecedents and Adaptations",79 Harv. L. Rev. 1207-1224 (1966); M. CAPPELLial Review in the Contemporary World, Indianapolis, Bobbs-Merrill, 1971, 24-43 [doravante citada como Judicial Review]. 
instituições e processos, numa tentativa de limitar e controlar o poder político. Existe, naturalmente, uma variedade de meios que ajudam a alcançar este desiderato. Esses meios incluem o regionalismo, que traz à tona a descentralização, pelo menos de parte do poder político, uma forma de "divisão vertical" do mesmo. Aqui, todavia, eu pretendo centrar minha discussão a respeito da revisão judicial da constitucionalidade do ato administrativo e particularmente, da legislação. Trata-se de uma evolução que, num sentido mais real, mudou a estrutura governamental na maior parte da Europa continental, nos últimos 40 anos mais ou menos, com expansões em outras partes do mundo, incluindo, por exemplo, o Japão.

\section{O Surgimento e o Cresci- mento da Justiça Constitucional na Era Posterior à II Guerra Mundial}

A Áustria desde 1945, o Japão desde 1947, a Itália desde 1948, a Alemanha desde 1949: emergindo do pesadelo da tirania e da guerra, todos esses países percorreram um caminho semelhante em seus esforços de construção duma nova forma de governo civil e democrático. Cada um deles adotou uma Constituição escrita, aceita como obrigatória por todos os órgãos do governo. Introduziram severas limitações ao processo de emenda à Constituição, protegendo assim o novo direito fundamental, dos caprichos de maiorias passageiras. Incluíram direitos fundamentais na
Constituição, estendendo, assim, a proteção constitucional aos indivíduos em face do poder governamental; e, last but not least, reforçaram a atuação da Constituição e de seus direitos fundamentais, em relação a novos ou reestruturados tribunais judiciais, dotados de importantes garantias de independência face a órgãos políticos. 5

Isso, naturalmente, pode parecer um pouco banal para os americanos. Permitam-me advertir, todavia, que mesmo neste país, o papel da decisão constitucional adquiriu sua importância atual somente depois da II Guerra Mundial, quando se tornou o mais importante instrumento para a garantia de certos direitos civis básicos dos cidadãos e de grupos minoritários contra maiorias resistentes nos Estados e da inação de órgãos políticos no plano federal. Quanto ao resto do mundo, notase que em muitos outros países a justiça constitucional, em todos os sentidos até agora mencionados, representou um inovação fundamental. Realmente, foi uma verdadeira revolução, ao menos na Europa continental e, talvez, no Japão.

Constituições e direitos fundamentais, é claro, existiram na França, na Alemanha e em outros lugares, por muitos anos. Até a época que se seguiu à II Guerra Mundial, todavia, seus significados tendiam a ser compreendidos mais como meras declarações político-filosóficas do que como atos legalmente obrigatórios. $\mathrm{E}$ isso porque, com poucas e esporádicas exceções de curta duração (mais marcadamente as da Áustria em 1920 e início de 1930$)^{6}$, nenhum órgão independente tinha a prerrogativa de
${ }^{5}$ Sobre estes desdobramentos vide Judicial Review, supra nota 4, especialmente cap. 3. A principal característica dos sistemas europeus de revisão é sua natureza "centralizada", vale dizer, que a autoridade para declarar uma lei inconstitucional, logo (em princípio) nula e ineficaz, está restrita à revisão da recém criada Corte Constitucional. Se confrontada com a questão da inconstitucionalidade da lei relevante no caso em espécie, as outras cortes não decidirão mas sim suspenderão o feito e reverterão a decisão de constitucionalidade à Corte constitucional cuja decisões têm efeito erga omnes. Os sistemas europeus são contrastantes com o sistema americano "desceujas zado" em que as cortes têm o poder revisional. Vide Judicial Review supra nota 4 , caps, 3-5. ${ }^{6}$ Vide $i d .$, p. 46-47 et passim.

Revista da Faculdade de Direito da UFRGS, v. 20, Outubro/2001 supervisionar suas reais aplicações. A revolução constitucional - e eu realmente entendo o que estas palavras significam somente ocorreu na Europa com o doloroso entendimento de que a Constituição e os direitos fundamentais constitucionais necessitam de uma máquina judiciária para se tornarem efetivos. Os Estados Unidos certamente concorreram com um influente precedente. Mas a mais marcante lição veio da experiência doméstica, da experiência de tirania e de opressão por um poder político sem freios, por uma máquina ao mesmo tempo acessivel às vítimas do abuso governamental e capaz de restringir tal abuso.

A lição foi eventualmente apreendida. Cortes constitucionais foram criadas e processos constitucionais esboçados para fazê-las funcionar. Menciono apenas um desse processos, porque parece ser o mais indicativo de uma filosofia permeando essa revolução constitucional de direitos civis. Na Alemanha, em 1951, a legislação ordinária concedeu qualquer cidadão o direito de demandar perante a recém criada Corte Constitucional, contra qualquer ato do Estado, legislativo, administrativo ou judicial, que violasse direito constitucionalmente protegidos ${ }^{7}$. Em 1969 este extraordinário remédio, chamado "Verfassungsbeschwerde", ou queix constitucional, foi introduzido na Constituição

alemã, e na Áustria, especialmente desde 1975 , foi adotado um processo similar ${ }^{8}$. Através desse e de outros mecanismos a constitucionalidade de milhares de atos legislativos e de outros administrativos foi controlada e os direitos fundamentais do povo protegidos por Cortes independentes, na Alemanha, na Áustria, na Itália e em outros lugares.

O sucesso da "justiça constitucional", como instrumento para a proteção dos direitos humanos, e seu profundo impacto na forma de liberdade democrática de governo, tem sido geralmente reconhecido em todos esses países, muito embora, como é natural, a dissensão muitas vezes diga respeito ao conteúdo das decisões constitucionais particulares ou mesmo acerca de algumas tendências generalizantes no caso do direito constitucional. Talvez a mais conclusiva evidência, do sucesso deste fenomenal desenvolvimento conceitual seja dada por sua tremenda força de expansão. Refiro alguns episódios: Chipre em 1960, Turquia em 1961, e Malta em 1964, todos introduziram formas de jurisdição constitucional largamente inspirados nos modelos da Alemanha, Áustria, e Itália ${ }^{9}$. Realmente, parece que nenhum país da Europa, emergindo de alguma forma de regime não democrático ou de sérios conflitos domésticos, poderia achar uma melhor resposta à exigência de reagir contra pecados passados,

${ }^{7}$ Vide id., p. 22-23. Para prevenir o abuso deste processo, é necessário ocorrer a exaustão dos remédios normais, mas mesmo este pré-requisito não é necessário no caso de uma queixa refletindo um "interesse geral" ou quando a demora poderia ocasionar importante prejuízo à parte interessada. Vide, v.g., K. SCHLAICH, "Procédures et techniques de protection des droits fondamentaux. Tribunal Constitutionnel Fédéral Allemand," in Louis FAVOREU (sob a direção de), Cours constitutionnelles européennes et fondamentaux, Paris, Econômica, 1982, p. 128-129 [doravante citada como Cours constitutionnels].

${ }^{8}$ Vide o relatório de L. Favoreu sobre a Europa Ocidental, §§ 8-10, apresentado na Conferência da Associação Internacional de Ciência Legal, realizada em junho de 1984, em Uppsala, Suécia, no "Judicial Review at Legislation and its Legitimate - Recent Developments" Os relatórios regionais, tanto quanto o relatório geral de CAPPELLETTI form publicas em forma de volume sob a edich

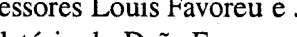
publicada in Revue du droit public et de la science politique en France et à l'étranger, 1984, 1147-1201).

${ }_{9}^{9}$ Constituições de Chipre (1960), Turquia (1961) e Malta (1964), Vide Judicial Review, supra nota 4, p. 50-51. 
e, possivelmente prevenindo uma recaída, do que introduzindo a justiça constitucional em seu novo sistema de governo. Foi o caso da Grécia em 1975, depois da queda do regime dos coronéis, ${ }^{10}$ de Portugal em 1976, depois da queda do regime de Salazar ${ }^{11}$; e da Espanha, depois da queda de Franco ${ }^{12}$. Significativamente, também a Iugoslávia, na procura de uma autonomia política e ideológica vis-à-vis da União Soviética, promulgou uma constituição em 1963 que introduziu um sistema de revisão judicial ${ }^{13}$. A Iugoslávia foi o primeiro e, até agora, o único país de regime comunista a fazer isso; mas é bastante significativo que a Tchecoslováquia em 1968 - o ano das paixões e esperanças da "Primavera de Praga" - tenha tentado logo a seguir ${ }^{14}$ uma experiência semelhante, e que assim o tenha feito a Polônia, em 1982, antes de o "Solidariedade" e todo o resto terem sido condenados ao silêncio ${ }^{15}$ Diferentemente da Iugoslávia, entretanto, as emendas constitucionais da Tchecoslováquia e da Polônia permaneceram letra morta, esmagadas pela ressurgência de seus regimes autocráticos. Realmente, se uma boa lição claramente emerge da análise comparativa desses acontecimentos mais recentes, uma lição que muitos críticos da legitimidade democrática da revisão judicial parecem negligenciar, é a de que nenhum sistema efetivo de controle judicial é compatível ou tolerado por regimes antilibertários e autocráticos, quer se coloquem à esquerda ou à direita dum espectro político. $\mathrm{O}$ fato de que a revisão judicial se constitui em um anátema à tirania, é confirmado pelo seu desenvolvimento em vários continentes, e mais freqüentemente na América Latina e África ${ }^{16}$. Uma ilustração peculiar oferece a África do Sul,

${ }^{10}$ Constituição Grega de 1975. Vide E.SPILIOTOPOULOS, "Judicial Review of Legislative Acts in Greece", 56 Temple Law Quartely 463 (1983); J. ILIOPOULOS-STRANGAS, "Grundrechtsschutz in Griechenland”, Jarhbuch des oeffentlichen Rechts, 1983, 396; V. Perifanaki ROTOLO, "La Corte Suprema Speciale nella Costituzione Greca del 1975", 29 Rivista trim. di diritto pubblico 183 (1979); L. FAVOREU, supra nota 8, §§ 27-31. Sob o sistema grego, todas as cortes têm o poder de negar aplicação de leis inconstitucionais (assim o chamado sistema de revisão "descentralizado", vide nota 5 supra), mas uma recém instituída "Suprema Corte Especial" tem a palavra final no caso de opiniões conflitantes entre as altas cortes.

${ }^{11}$ Constituição Portuguesa de 1976. Especialmente após a reforma constitucional de 1982, Portugal adotou um sistema de revisão judicial similar àquele prevalecente na maioria das nações européias mencionadas no texto, confiando a função de controle a uma recém criada Corte constitucional. Vide L. FAVOREU, supra nota 8 , §§ 22 26; H. FIX-ZAMUDIO, La protección jurídica y procesal de los derechos humanos ante las jurisdicciones nacionales, Madrid, Civitas, 1982, 203-207.

${ }_{12}$ Constituição da Espanha de 1978, seguida pela criação em 1980 de um tribunal constitucional bastante ativo. Vide E. GARCIA DE ENTERRIA, La constitución como norma y tribunal constitucional, Madrid, Civitas, $2^{\mathrm{a}}$ ed., 1982; J. GONZÁLEZ PÉREZ, Derecho procesal constitucional, Madrid, Civitas, 1980; M. ARAGÓN REYES, "El control de constitucionalidad en la Constitución española de 1978", 7 Revista de Estudios Politicos 171 (1979); H. FIX. ZAMUDIO, supra nota 11, 197-202; FAVOREU, supra nota 8, §§ 13-14.

${ }^{13} \mathrm{O}$ sistema foi reafirmado na Constituição da Iugoslávia de 1974. Vide o relatório de Uppsala por Pavle NIKOLIC sobre as nações socialistas, supra nota 8, \&\$ I. 1, III. 2. A et passim; vide também H. F. FIX-ZAMUDIO supra nota 11, 208-212; Judicial Review, supra nota 4, 51-52.

${ }^{14}$ Vide relatório Uppsala por P. NICKLIC, supra nota 13, § III. 2. B.; relatório geral de Uppsala por M. CAPPELLETTI, supra nota $8, \S 2$.

${ }^{15}$ Vide A GWIZDZ, "The Constitutional Review of Laws in Poland", relatório polonês do $1^{\circ}$ Congresso da Associação Internacional de Direito Constitucional realizado em Belgrado, setembro de 1983 (não publicado) relatório de Uppsala por P. NIKOLIC supra nota 13, § III. 2. C; relatório geral de Uppsala por M. CAPPELLETTI, supra nota $8, \S 2$.

${ }^{16}$ Vide os iluminados relatórios de Uppsala por J. CARPIZO \& H. FIX-ZAMUDIO sobre a América Latina e por B. O NWABUEZE sobre a África, supra nota 8.

Revista da Faculdade de Direito da UFRGS, v. 20, Outubro/2001 onde uma "crise constitucional" desenvolvida em 1950 irrompeu no momento em que o Judiciário deciarou inconstitucionais certas promulgações do Parlamento Sul Africano. A crise culminou com a adoção da Constituição Sul Africana de 1961, que efetivamente negava ao Judiciário qualquer autoridade para revisar a validade dos atos legislativos. ${ }^{17}$
IV. A França Repudiou Montesquieu?

Não sou um especialista em assuntos japoneses. Sei, todavia, que, mesmo naquela nação, a justiça constitucional, inicialmente vista por muitos como um elemento alienígena

A história Sul-Africana de luta de uma corte contra alguns excessos de um regime não liberal é muito sugestiva merece ser relembrada com certos detalhes. A "crise constitucional" daquele país pode ser remontada à decisão da Suprema Corte da África do Sul no ano de 1952 no caso de Harris e outros v. Ministro do Interior, 1952 (2) A 428 (A.D.), também conhecido como o caso do Voto. Na decisão, a Corte manto e fundamental de desqualificar Representação Separada do Ato dos Elet orte decidiu que isto violava algumas seções "enraizadas" na Constituiçãa Sul-Africana (Ato da Arica do Sul de 1909), particularmente a seção 35 que dispunha que "nenhuma lei...desqualificará qualquer pessoa ...que é ou possa vir a ser capaz de se registrar como votante...somente em razão de sua raça, a não ser que [aprovada por maioria de dois terços do Senado e da Câmara dos Deputados em sessão conjunta]. Naquele tempo, a autoridade de revisão juridicial da Suprema Corte com respeito às seções "enraizadas" era motivo de grande debate e a decisão do Presidente da Suprema Corte, A. van de Sant Centives (que foi declarada pelo menos por um comentarista - o então Deão da Escola de Direito de Harvard, Ervin Griswold - Ombrear com as melhore decisões sobre direito constitur Harv. L. R. 1361 [1953]), criou uma enorme conpetente para determinar se um Ato do Parlamento havia sido Corte Centlivres declarou que a corte era competente significaria dizer que as cortes de justiça não teriam poder vara proteger os direitos dos indivíduos que estavam especialmente protegidos pela constituição deste país." O para proteger os 479 . O governo da África do Sul não ficou satisfeito com a decisão sobre o Voto e mais tarde, em 1952, cada uma das casas do Parlamento por maioria simples de votos promulgou o Ato da Alta Corte do Parlamento, 35 de 1952, que criou a "Alta Corte" da qual cada membro do Parlamento seria membro. A "Alta Corte" foi declarada como sendo uma corte de direito com poder de revisão de qualquer decisão da Suprema Corte que declarasse atos do Parlamento como inválidos. A "Alta Corte" procedeu então a revisão dram mais aplicáveis. derrogou sob a alegação de que as seçôes "enaizadas cas Cola Suprema Corte como inválido, concordando os O Ato da Alta Corte, todavia, j69 (A. D.) Finalmente, em 1955, em outra tentativa de passar por cima de um Judiciário "pouco amigável", . das duas casas do Congresso o Governo teria uma maioria de dois terços de todos os membros das duas Casas. O Ato do Senado, 53, de 1955. No ano seguinte, o Ato de Emenda Sul-Africana, 9 de 1956, foi aprovado por uma sessão conjunta. Essa emenda constitucional alterou consideravelmente as cláusulas pétreas da Constituição e particularmente derrogou a seção 35 relativa aos direitos de desquallficaça do voto. A emenda constitucional tambem considerou a revisão judicial. A seção 2 estabelecia em para investigar ou pronunciar-se sobre a validade de lei aprovada pelo Paráamentótreas foram consideravelmente seções "enraizadas"]. E claro, como previamente notado, que as seçôes pétreas foram coram ameaçados mas enfraquecidas pela envia. retirar os poderes de voto dos negros do Cabo tal como originariamente tentado em 1951. A indignação causada por esses desdobramentos foi finalmente acalmada em 1961, quando a Africa do Sul formalmente tornou-se uma República. A constituição Sul-Africana de 1961 refletia inteiramente as enfraquecidas secções pétreas e o significado da emenda de 1956. Essa ausência de revisáo judicial foi mantida na da $\mathrm{A}$ (n) do Su de implica $\mathrm{Am}$ um Constituição, todavia, incorporou uma terminologia de direitos politicos em seu preâmbulo e pode implicar em úm papel constitucional mais auante do Sul é algo que permanece em dúvida. Para maiores discussões da "crise constitucional da Africa do Sul em vide H.J.MAY, The South African Constitution, 3 ed., Capetown 7 (1958). Para maiores discussões sobre a revisão Audicial System and its backgrounded, Cape Town, Juta \& Co., 1968, 53-63; L. A. ROSE INNES, Judicial Review of Administrative Tribunals in South Africa, Capetown, Juta \& Co., 1963, 1-20. Para discussão da Constituição da África do Sul de 1983 e melhor bibliografia vide L. J. BOULLE, Conntitutional Reform and Apartheid, New York, St. Martin's Press, 1984.

Revista da Faculdade de Direito da UFRGS, v. 20, Outubro/2001 
no sistema de governo japonês, gradualmente construiu para si uma relevante função e uma significação genuína dentro do sistema, mesmo que nem tão importante e significativa quanto a da Europa Continental. ${ }^{18}$

Retornando à Europa, meu relato seria um tanto quanto incompleto caso não dissesse algo a respeito de outras duas grandes nações: a França e a Inglaterra. Esses países têm sido muito mais relutantes do que a maior parte da Europa em participar da "revolução constitucional". Neles, a supremacia parlamentar se enraizou de há muito como um credo político - de tal forma que o Parlamento nacional, como incorporação da vontade democrática, tem-se mostrado imune ao controle judicial. Essa tem sido a tradição e o mito; na Inglaterra desde a "Revolução Gloriosa" de 1688, e na França desde sua Revolução um século depois; mito de que não compartilha a Revolução Americana. ${ }^{19}$

Para dizer a verdade, cada uma dessas duas nações européias tem uma história diferente acerca da supremacia parlamentar $\mathrm{Na}$ França, é mister voltar-se ao passado para nele encontrar um profundo sentimento de repulsa popular contra o abuso da função jurisdicional exercido pelas as altas cortes de justiça no tempo do ancien régime. Esses tribunais, ironicamente denominados de Parlaments, tinham competência para rever atos do soberano, recusando-se a aplicar os considerados incompatíveis com "as leis fundamentais do reino". ${ }^{20}$ Os pronunciamentos - na maior parte não escritos - acerca dessas leis fundamentais, entretanto, induziram as cortes a afirmar a "heureuse impuissance" do legislador até mesmo introduzindo pequenas reformas liberais. Os juizes estavam de tal maneira identificados com o regime feudal que consideravam inaceitável qualquer inovação liberal. Os cargos eram hereditários, podendo ser comprados e vendidos. ${ }^{21} \mathrm{O}$ trabalho dos juízes devia ser pago pelos litigantes como se a administração da justiça ${ }^{22}$ fosse um privilégio dos magistrados e não uma obrigação. Status, educação, família e interesses pessoais de classe se combinavam para motivar comportamentos extremamente conservadores, fato que, eventualmente, contribuiu para a

${ }^{18}$ Vide relatório Uppsala por Y. Taniguchi sobre o Japão, supra nota 8.

${ }^{19}$ Talvez a razão histórica para esta diferença básica, que se reflete na profunda diferença entre as versões francesas e americanas de "separação de poderes" (vide texto acompanhando e seguindo nota 33, infra), encontra-se no fato de que a americana independe do Parlamento Britânico. Isto pode explicar por que, como diz o Professor HENKIN, os constituintes da Constituição Americana "não estavam contentes com a democracia, nem mesmo com o governo representativo, pois tinham apreendido que o Parlamento também poderia ser despótico". Louis BENKIN, The Rights of Man Today, Boulder, Colorado, Westview Press, 1978 p. 10, repetindo The Federalist n. ${ }^{\circ} 4$ (James MADISON): "A acumulação de todos os poderes, legislativo, executivo e judiciário nas mesmas mãos, se em uma, algumas, ou muitas, e se hereditária, autonomeada, ou eletiva, pode ser justamente declarada como a exata definição da tirania."

${ }^{20} \mathrm{O}$ desenvolvimento gradual e as conseqüências políticas do "poder dos Parlements de vetarem a legislação real" $1968,362-371$. O poder de veto foi exercido por ambos, face à recusa de registrar as proclamações reais nos registros do Parlement e pelo protesto público (remonstrance) contra um ato real de que o Parlement desaprovava. ${ }^{21}$ Vide, v.g., J. P. DAWSON, supra nota 20, p. 350-362

${ }^{22} \mathrm{O}$ assim denominado "princípio da venalidade da justiça" foi abolido na França pela Revolução através da lei de agosto 16-24, 1790, tit. II, art. 1 Vide M. CAPPELLETTI \& J. GORDLEY, "Legal Aid: Modern Themes and Variations", 24 Stanford Law Rev. 347, 355 (1972).

Revista da Faculdade de Direito da UFRGS, v. 20, Outubro/2001 deflagração da explosão revolucionária ${ }^{23}$. O ressentimento popular contra os Parlements era justificado ${ }^{24}$ e refletiu-se,
por vezes em forma velada, na celebrada obra, De L'Esprit des Lois, publicada pela primeira vez, em 1748 , por quem, ao falar dos juizes de seu tempo e país, sabia muito bem o que estava dizendo. Charles-Louis de Secondat, o primogênito duma antiga família de juizes "parlamentares", contando 27 anos de idade, em 1716, já se tinha tornado "Président à mortier" no "Parlement" de Bordeaux. Herdara o alto cargo judiciário, assim como o nome de Montesquieu, de seu falecido tio ${ }^{25}$ Perfeitamente compreensível, dado o tipo de juízes daquele tempo, pregasse um iluminado Montesquieu que os juízes não deveriam ser investidos de nenhum poder político:

Não há liberdade .....se o poder de julgar não está separado do poder legislativo e do executivo ${ }^{26}$.

"Mesmo que a lei", diz ele, "embora clarividente e cega" 27 , parecesse em certos casos cruel, ainda assim não seria dado aos juízes interferirem; pois esta tarefa é da competência exclusiva dos legisladores. Aos juizes incumbe o dever de aplicar a le cegamente, uma vez que os juizes não são nada mais do que a boca que pronuncia as palavras da lei; são seres inanimados que

23 "Por volta de 1750 os Parlements tinham emergido como uma bem articulada e determinada oposição, ${ }^{23}$ "Por resistindo a todos os fireitos fundamentais do reino $\mathrm{e}$ tos fundamentavam suas demandes privilégios da alegavam estar resguardando suas liberdades... A conistra ." . P. DAWSON, supra nota 20, p. 369.

nobreza e da resistência a todas as mudanças na admistraça " "Juando se considera a selvageria do ressentimento ${ }^{24} \mathrm{~A}$ Revolução prontame isto largamente deveu-se ao fato de muitos se terem exilado." J. P. DAWSON, supra nota 20, p. 370. "A mais alta isto largamente deveu-se ao fato de mutamentaires de Toulouse ( 55 executados, i.e., 50 porcento). Bordeaux for taxa de mortalidade recaiu sobre os parlamentaires de $370, \mathrm{n}^{\circ} 22$.

$370, \mathrm{n}^{\circ} 22$.
${ }^{25}$ Vide Robert DERATHÉ, in MONTESQUIEU, De L'Esprit des Lois", Tomo I, Paris, Editions Garnier Frères, 1973, p. LXVII-LXVIII.

${ }^{26}$ De L'Esprit des Lois, livro XI, cap. VI (traduções desse artigo, senão diferentemente indicado, são de M. CAPPELLETTI).

${ }^{27}$ Ibidem.

Revista da Faculdade de Direito da UFRGS, v. 20, Outubro/200/ 
não podem moderar quer a força quer o rigor da lei ${ }^{28}$.
Embora Montesquieu, diferentemente de Locke, tenha apresentado o ${ }^{28}$ Ibidem. A teoria de Montesquieu tem, nada obstante, várias ambiguidades. Contrariamente a J. J. ROUSSEAU,
que era a favor de um governo "republicano" - i. e., de um governo "guiado pela vontade geral, que é a lei" (Jeanque era a favor de um governo "republicano" - i. e., de um governo "guiado pela vontade geral, que é a lei" (Jean
Jacques ROUSSEAU, Du Contrat Social ou Principes du Droit Politique, livro II, cap. VI, nota 1 et passim) ou, na definição de Montesquieu, de um governo no qual "o povo...tem o poder soberano" (MONTESQUIEU, ob. cit., livro II, cap. 1) - Monstequieu advogava uma monarquia moderada, não absoluta, ou, como nós a chamamos hoje uma monarquia constitucional (livro II, cap. IV e livro V, cap. XI), enquanto condenava a forma despótica de governo (livro II, cap. V e livro V, cap. XIV). A monarquia de Montesquieu era por ele caracterizada como un sistema em que "somente uma pessoa governa, mas com base em leis fixas e estabelecidas" (livro II, cap. 1)
contrastava com o regime despótico em que "uma pessoa decide tudo, sem leis nem regras, meramente baseada em sua vontade e caprichos" (ibidem). Ele enfatizou, repetidamente, que o monarca não despótico estará obrigado por "direitos fundamentais" (livro II, cap. IV; livro V, cap. XI) e não deverá concentrar em si a função judicia (livro VI, cap. V). Assim agindo, todavia, Montesquieu parecia apoiar exatamente o que os Parlements tinhan tentado fazer por um longo tempo - impor, mesmo contra o monarca, a superioridade de certas leis não escritas "leges generales" ou direitos fundamentais, "fixes et immuables", que, no entanto, devido a sua essencialmente doutrina da superioridade "dos direitos fundamentais do reino" leva os Parlements a exercerem aquilo que redundava ser uma revisão judicial da legislação. Vide Judicial Review, supra nota 4, 32-36; e vide o texto e nota 20, supra. Há no mínimo duas passagens no L'Esprit des Lois, nas quais Montesquieu parece apoiar essa função jurisdicional dos Parlements: no livro III, cap. X, onde ele lamenta que nos regimes despóticos, o "príncipe" requer obediência absoluta a seus desejos e nenhuma "remonstrance" é permitida; e no livro V, cap. X, onde ele pessoa, mais eficiente e prontamente do que no governo "republicano", tal eficiência não degenera em descaso porque a ação estatal é constrangida ao respeito às leis. Teria então Montesquieu "repudiado" - ou de fato contraditado a si mesmo? Onde estará o "verdadeiro" Montesquieu? Como poderiam tais passagens ser reconciliadas com o contínuo apelo no sentido de que as decisôes não deveriam ser "arbitrárias" (ivro XI, cap. VI); que nas boas monarquias a virtude do juiz encontra-se na "la médiocrité" (livro XX, cap. XIII); que os juízes estão obrigados a aplicar rigorosamente "la loi" ("onde necessário, o juiz simplesmente a segue; onde não, ele procur
seu espírito") (livro VI.., cap. III; que o julgamento não refletirá as opiniôes pessoais do juiz (livro XI, cap. VI); que nenhuma liberdade existe quando o juiz é também o legislador (livro XI, cap. VI); em suma, que o juiz deve ser somente a "inanimada" boca da lei (ibidem)? Uma explicação, naturalmente, poderia ser a influência das teorias do direito natural dominante em toda a Europa nos séculos XVII-XVIII com os quais Montesquieu compactuo (vide, v.g., livro I, cap. II, para uma estudada interpretação vide R. SHACKLETON, "Montesquieu em 1948", Estudos Franceses $299,303-323$ (1949)). Tais teorias afirmam a existência de certos direitos, enraizados na natureza ou na razão humanas, imutáveis e universais e superiores ao direito positivo de um dado tempo e lugar
Essas teorias também eram dificilmente compatíveis com um papel puramente mecânico do juiz. No entanto, afora a obediência e a aplicacão do direito natural, eram para serem relegadas à exclusiva preocupação do soberano, como na concep̧̧ão de Hobbes, que fol severamente condenado por Montesquieu (vide R. SHACKELTON, "Montesquieu em 1948", 3 Estudos Franceses 299, p. 310-311 (1949). Uma outra explicação pode ser a de que Montesqueu não atribuía afinal de contas uma importância muito grande aos "direitos naturais" na determinação do papel dos juízes. Deve-se notar que, muito embora mesmo os reis de França admitindo a existência de tais regulava a sucessão à coroa (Lei Sálica) e o direito que estabelecia a inalterabilidade do domínio real" (assim R. DERATHE, supra nota 25 , p. 430). Isso, naturalmente, era muito pouco, para representar a fundamentação de um sistema de revisão judicial da legislaçâo monárquica. Uma terceira explicação, que parece mais plausível é a da visăo de Montesquieu em defesa de uma "monarquia moderada" em que os poderes do monarca estavam mai limitados pelos "poderes intermediários" (vide v.g., De Lesprit des Lois, livro II, cap. IV) e mais particularmente não parece convincente: mesmo o assim chamado "eloge de l'état de la robe" por Montesquieu no livro XX, cap. XXIl está longe de significar o que DERATHÉ parece sugerir. Porque, conforme o já mencionado, mesmo Montesquieu magnificava a "médiocrite" e a "suffisance" do juiz "parlamantaire", embora pagasse um tributo à "gloire" do "corps" como tal; a glória, a qualquer custo, que e imediatamente declarada bastante inferior àquela da desta recomenda $\tilde{a}^{\circ}$, não muitas décadas depois a Franca e no despertar da França, grande parte do o espírito europeu, acabou por introduzir a carreira judiciária, preenchida por servidores públicos - a glória real da médiocrité Como tentei demonstrar em outra ocasião (vide Judicial Review, supra nota 4, p. 60-66 e "The Doctrine of Stare Decisis and the Civil Law", in Festschrift für Konrad Zweigert, H. Berstein, U. Drobing \& H. Kötz eds., Tübingen Mohr, 1981, 381, 387-393), esta "mediocridade " social e profissional dos juizes ordinarios continentais ("Civis") tornar-se-ia uma das razões por que eles se tornariam inadequados para o desafiador papel da revisão judicial dos precisaram ser criadas no século XIX e especialmente as cortes constitucionais em nosso século para preencherem aquele papel. Hoje, os juizes administrativos e até mesmo os constitucionais na Europa assemelham-se muito mais aos juízes federais americanos do que aos simples juizes de carreira.

Revista da Faculdade de Direito da UFRGS, v. 20, Outubro/2001 judiciário como um dos "três poderes", seguindo-se ao legislativo e ao executivo" deixou claro, contudo, que este terceiro ramo, na realidade, não é um "poder"

Dos três poderes de que falamos, judiciário é, em certo sentido, nulo. ${ }^{30}$

Qualquer que tenha sido a real influência de Montesquieu na Revolução Francesa, essa idéia deveria tornar-se a parte central de sua ideologia. A Revolução proclamou, como um de seus primeiros princípios, a absoluta supremacia do direito escrito; do direito originado do corps législatif por representantes do povo, enquanto reduzia o judiciário a desempenhar uma tarefa puramente mecânica de aplicação da lei aos casos concretos. Naturalmente, também a fé roussoniana na "infallibilité" da "loi", como expressão da "volonté générale", encontrou sua maior expressão neste desdobramento revolucionário. ${ }^{31}$

Na realidade, a estrita separação, "French style", dos poderes governamentais", se de inspiração realmente 32 "montesquiana" ou não, estava a milhas de distância do tipo da

${ }^{29}$ De L'Esprit des Lois, livro XI, cap. VI.

${ }^{30}$ Ibidem.

${ }^{31}$ Ibidem. ${ }^{32}$ A influência dos "ditames da lógica de Montesquieu nanãąa judicial francesa" é afirmada por J. P. DAWSON mentais que permaneceuco

supra nota 20, p. 376. ${ }^{33} \mathrm{~A}$ freqüente afirmação feita de que "a Constituição dos Estados Unidos compre. Dictionary of the History of Montesquieu)" da separação dos poderes - como se pode ler, .g., in P. P. Wímo, de justificação duvidosa. O fato Ideas, II, New York, Charles Scribe's Sons, 1973, 251 - e, para dizr o man é que a "séparation des pouvoirs", do modelo francês, é algo muito diferente do que sua Tradition. $2^{2}$ ed., Stanford, descrita como "de pesos e contrapesos". Vide, v.g., J. H. MERRYMAN, The Civil Law Tradici, 2 ed., Stanford Cal. Stanford University Press, 1985, 15-16; Sir Otto KAHN-FREUND, Common Law and Civil Law in Imaginary and Real Obstacles to Assimilation", in M. CAPPELLETT1, ed., New Perspectives for a Common Law of Europe, and Real Obstas Leyden \& Bruxelles, Sijhó \& BIX e da justice constitutionnelle em nosso tempo, sobre a qual vide infra nesta Justice administrative no século XIX él se a afirmação acima fosse correta.

seção, seria totalmente incomprens. Vide, vg. Alf Ross, sobre Direito e justiça, Berkeley, University of California Press, ${ }^{34}$ Até os positivistas legais concordam. Vide, v.g., Alf Ross, sobca Dão da lei"); H. L. A. HART, supra nota 2, p. 629 ("a lei 1959, 284 ("nenhuma situação concreta permite una e não sobre a escolha propriamente dita").

$\frac{\text { existente impõe limites somente em nossa escolha e não sobre a escolha propriamente dita })}{\text { Revista da Faculdade de Direito da UFRGS, v. 20, Outubro/2001 }}$ separação dos poderes praticamente adotada A separação dos poderes na América é melhor caracterizada como "pesos e contrapesos" função extremamente importante de rever atos do legislativo e da administração. "Séparation mplicava que o judiciário deveria a qualquer preço assumir um papel totalmente a atividade dos órgãos políticos. Essa problemas e dificuldades não menos sérias do que as que tentava solucionar. A história legal é a ilustração contínua de tais problemas, tanto quanto de enormes esforços para os mesmos problemas. Com isso reduziu-se a máquina caça-níqueis de aplicação das leis a casos individuais, indiferente à realidade, isto poderiam ser tão claros e completos senão para permitir uma única e "correta" interpretação $0^{34}$. 
De modo ainda mais importante, modelo montesquiano (e roussoniano), tal como introduzido pela legislação Revolucionária Francesa - enquanto tentativa de proteção contra a tirania -, deixou as portas abertas às tiranias do legislativo e do executivo. A famosa loi revolucionária de 16-24 Agosto de 1790 da "organization judiciaire" - cujos princípios dever-se-iam tornar os pilares do sistema judicial francês e de outros sistemas continentais, influenciados pela França estabeleceu que não seria permitido nenhum controle pelo judiciário de atos legislativos ou administrativos:

Título II, Art. 10: Os tribunais judiciários não tomarão parte, direta ou indiretamente, n exercício do poder legislativo, nem impedirão ou suspenderão a execução de decisões do poder legislativo...

Título II, Art. 12: (Os tribunais judiciários) reportar-se-ão ao corpo legislativo sempre que assim considerarem necessário, fim de interpretar ou editar uma nova lei.

Título II, Art. 12: As funções judiciárias são distintas e sempre permanecerão separada das funções administrativas. Sob pena de perda de seus cargos, os juizes de nenhuma maneir interferirão com a administração pública, nem convocarão os administradores à prestação de contas com respeito ao exercício de suas funções. ${ }^{35}$

Isso significa dizer que tanto os legisladores quanto os administradore

públicos estavam isentos de qualquer controle por parte de um terceiro órgão, independente, apolítico ou, de alguma forma, menos político Os controles internos, naturalmente, poderiam ser e de fato foram estabelecidos. Mas a história não raro neste ponto de forma infeliz, provou que, para serem efetivos, os controles dos órgãos políticos dificilmente podem se controlados de dentro. Um poder executivo eficiente é hierarquizado. Não permite, em seu mais alto nível, um fácil controle interno independente, e isto não é menos verdadeiro para o poder legislativo, que se afirma como supremo. Deve se admitir, sem surpresa portanto, que todos os sistemas passados e presentes de controle político e não judicial, como os experimentados na França com as Constituições de 1799,1852 e 1946, e os correntemente adotados por muitos países comunistas, revelaram-se extremamente ineficientes ${ }^{36}$. O controle efetivo dos órgãos políticos necessita ser realizado de fora: precisa ser confiado a pessoas e as agências suficientemente independentes em relação aos órgãos controlados. E disso, de fato, os franceses gradualmente se deram conta, pelo menos no tocante ao ato administrativo. O Conseil d' État, gloriosa instituição. gradualmente evoluiu, de mero departamento interno da administração, como inicialmente havia sido no século XIX, até tornar-se uma agência judicial independente, por todos reconhecida como uma alta corte da França. Seu papel é o de controlar a legitimidade do ato administrativo. Quanto mais importante e aceito

${ }^{35} \mathrm{O}$ texto completo da loi pode ser encontrada em J.B. DUVERGIER, Collection Complète des Lois, etc., I, Paris, Guyot et Scribe, 1834, 310-333.

${ }^{36}$ Para os precedentes franceses vide Judicial Review supra nota 4, p. 33 e as referências na nota 30 ibidem. A maioria das constituições européias orientais e outras dos países socialistas confiam o papel de controlar a constitucionalidade da legislação ao "Soviet Supremo" ou à "Assembléia Popular" e/ou aos "praesidiums". O constitucionalidade da legislação ao "Soviet Supremo" ou à "Assembléia Popular" e/ou aos "praesidiums". O
constitucionalista iugoslavo Pavle Nikolic em seu relatório de Uppsala sobre os países socialistas, supra nota 13 informa-nos que este "autocontrole, i.e., o controle da constitucionalidade da legislação confiada ao próprio corpo legislativo, provou ser ineficiente. Esta mesma ineficiência foi a maior razão que levou a Yugoslávia a adotar, e a Tchecoslováquia e a Polônia tentaram adotar, um sistema de revisão judicial no lugar de uma revisão política. Vide o relatório de NIKOLIC, §§ II. 2. I, III. 2. A B-C; e vide o texto e as notas 13-15 supra.

Revista da Faculdade de Direito da UFRGS, v. 20, Outubro/2001 se torna o papel do Conseil, tanto mais independente ele se apresenta vis-à-vis do órgãos políticos. E com sua independência, a natureza judicial do processo também fica cad vez mais acentuada e reconhecida, com todas as conseqüências de tal entendimento incluindo a adoção das salvaguardas mais características do processo judicial: imparcialidade do magistrado, o direito das partes de serem ouvidas e de todos os vários corolários dessas regras básicas da "justiça natural" ${ }^{37}$.

A França, naturalmente, foi o início, no velho continente, dessa evolução histórica: estabelecimento da justice administrative ou da revisão judicial dos atos administrativos. Cedo ou tarde, entretanto, outras nações continentais seguiram seu exemplo, e, assim, sistema de justice administrative francês tornou-se modelo do desenvolvimento de órgãos análogos, tais como a Verwaltungsgerichtsbarkeit, na Alemanha, e a giustizia amministrativa, na Itália, etc. ${ }^{38}$

Nosso século, todavia, haveria de ensinar uma outra lição: a de que a idéi roussoniana da infalibilidade da lei parlamentar não passava de outra ilusão ${ }^{39}$, pois até legislativo, e não apenas o executivo, pode abusar do poder. A experiência mostrou, além disso, que a possibilidade do abuso legislativo cresceu enormemente com o crescimento legiferante do estado moderno ${ }^{40}$, e, também que as tiranias legislativas e majoritárias podem ser tão opressivas quanto a tirania do executivo. É suficiente lembrar a legislação fascista, que

privou os judeus e outras minorias de seus direitos mais fundamentais. Essa é a razão por que a Áustria, a Itália e a Alemanha, emergindo do descalabro moral e material, da perversão política, da ditadura e da derrota, logo se voltaram para a justiça constitucional, como antes se aludiu, para criar um novo tipo de controle a ser acrescentado à justice administrative. Assim fazendo, tentavam limitar e controlar o poder do legislativo e da maioria legislativa, dentro do esquema da nova norma constitucional, tornada atuante pela decisão constitucional. A influência histórica das idéias francesas, entretanto, pode também ajudar a compreender porque essas nações sentiram a necessidade de seguir um caminho similar àquele da justice administrative: todas elas controlam os órgãos judiciais de controle do ato administrativo ${ }^{41}$ - criado que foi um novo tipo de órgão controlador, quase como um pendant do Conseil d' Etat do século XIX e de seus similares alemães e italianos.

A França, por outro lado, estava de algum modo menos envolvida nesse novo curso de ação. Os abusos do régime de Vichy durante a II Guerra Mundial foram talvez menos excessivos, e certamente menos duráveis do que em outros países. Isso pode explicar porque a França, muito embora a líder no século XIX no desenvolvimento da justice administrative, não desempenhou o mesmo papel no desenvolvimento da "constitutional justice" no mundo que se seguiu à II Guerra Mundial.

Todavia, isso não foi ainda o fim da atuação francesa. A França, embora não tenha

${ }^{37}$ Para uma breve idéia sobre o desenvolvimento da justice administrative na França vide L. N. BROWN \& J. F. GARNER, French Administrative Law, $3^{\mathrm{a}}$ ed., London, Butterworth, 1983, 28-31.

GARNER, French Administrative Law, $3^{a}$ ed., London, Butterworth, 1983, 28-31.
${ }_{38}$ A influência do sistema francês de justiça administrativa fora da França é discutida in id., 162-171. ${ }^{38}$ A influência do sistema francês de justiça administrativa fora da França é discutida in id., 162-171.

Constitutionnel et les Libertés, Paris, Economia, 1984, 166.

${ }^{40}$ Vide M. CAPPELLETTI, "Nécessité et Légitimité de la Justice Constitutionnelle", in Cursos Constitucionais, supra nota 7, 464-471 [doravante citada como "Nécessité et Légitimé"].

${ }^{41}$ Vide nota 5, supra. 
liderado o processo, envolveu-se ultimamente de maneira profunda num fato mais recente: $\mathrm{o}$ da revolução da revisão constitucional e judicial $^{42}$. Tal tornou-se patente especialmente a partir de 1971, quando o órgão criado pela Constituição de De Gaulle, de 1958, denominado Conseil Constitutionnel, corajosamente transformou seu papel, transmudando-o radicalmente. Originariamente, visto como mero vigia dos ampliados poderes do executivo sob o regime do Général, o Conseil Constitutionnel assentou-se pela primeira vez, em julho de 1971 , como um órgão independente, quase judicial, cujo papel era o de rever a constitucionalidade da legislação parlamentar, violadora de direitos fundamentais. Uma emenda constitucional de 1974, emitida durante o governo do Presidente Giscard d'Estaing, reforçou esse desenvolvimento, garantindo às minorias parlamentares de oposição o direito de questionarem a legislação perante o Conseil Constitutionnel. Hoje, muitos juristas concordam com nosso colega francês, o Deão Louis Favoreu, que manteve a opinião de que o sistema de revisão judicial da constitucionalidade da legislação, desenvolvido pela França durante os últimos quinze anos, é tão efetivo como o das nações continentais vizinhas ${ }^{43}$. No entanto, ao menos duas sérias limitações do sistema francês não devem ser desconsideradas ${ }^{44}$. Primeiro, na França não há possibilidade de os indivíduos, cujos direitos fundamentais tenham sido violados, levarem sua inconformidade ao Conseil Constitutionnel, uma vez que a legislação parlamentar somente pode ser atacada por pelo menos 60 membros de cada Casa do Congresso, ou por autoridades políticas que tenham representatividade individual para assim agirem no interesse geral. Segundo, a legislação só pode ser atacada durante o curto período entre sua aprovação pelo congresso e o de sua promulgação, porquanto, uma vez promulgada, nenhum juiz na França pode afastar uma loi, declarando-a conflitante com a Constituição. De mais a mais, mesmo nesses estreitos limites, a revisão judicial da legislação na França só se tornou expressiva há bem constitucionais das minorias e dos cidadãos encontraram nesse sistema revisional um formidável escudo contra o que era havido por muitos como um abuso da maioria. Assim, a Constituição francesa, e muito particularmente seus direitos fundamentais que, incluem a Déclaration des droits de l'homme et du citoyen, de 1789, tornou-se pela primeira vez, em toda a sua extensão $0^{45}$, legalmente obrigatória e judicialmente impositiva.

A Inglaterra, naturalmente, apresenta uma história muito diferente. Por um lado, contrariamente ao ancien régime da França, lá não houve nenhum profundo sentimento pouco tempo. Em muitos casos, os direitos

\section{A "Grundnorm" inglesa: A Absoluta Supremacia do Parlamento}

${ }^{42}$ Os desdobramentos na França são descritos por M. CAPPELLETTI, "The 'Mighty Problem' of Judicial Review and the Contribution of Comparative Analyses", 53 Southern California Law Rev. 409, 412-421 (1980) [doravante citada como “The Mighty Problem”]; vide também o relatório Uppsala por Favoreu, supra nota 8, §§ $15-20$.

${ }^{15}$-20.
${ }^{3}$ Relatório Uppsala por L. Favoreu, supra nota $8, \S 38$ et passim.

${ }^{43}$ Relatório Uppsala por L. Favoreu, supra nota 8, § 38 et passim.
${ }^{44}$ Sobre as "infirmações" do sistema francês vide "Nécessité et Légitimité", supra nota 40, 499-501.

${ }^{44}$ Sobre as "infirmações" do sistema francês vide "Nécessité et Légitimité", supra nota 40, 499-501.
${ }^{45}$ Algumas das decisões mais marcantes do Conseil Constitutionnel são traduzidas in M. CAPPELLETTI \& W. COHEN, Comparative Constitutional Law, Indianapolis, Bobbs-Merril, 1979, cap. 3. C e cap. 5.C. [doravante citado como Coparative Const. Law]. Vide L. FAVOREU \& L. PHILIP, Les Grandes Décisions du Conseil Constitutionnel, $3^{\mathrm{a}}$ ed., Paris, 1984.

Revista da Faculdade de Direito da UFRGS, v. 20, Outubro/2001 popular contra o judiciário, cujo histórico papel de proteção das liberdades individuais geralmente gozou de largo espectro ${ }^{46}$. Isso pode explicar porque, diferentemente da França, na Grã-Bretanha a revisão judicial do ato administrative nunca encontrou sérios obstáculos. A doutrina da separação dos poderes jamais foi inteiramente adotada na Inglaterra, em sua "versão francesa", isto é, na versão que implica a proibição de qualquer "interferência" dos tribunais nos órgãos da administração, e não somente no legislativo. Por outro lado, a Revolução Inglesa de 1688 afirmou, muito enfaticamente, a absoluta supremacia do Parlamento que, como diz o provérbio, "pode fazer tudo, menos transformar um homem em mulher ou uma mulher em homem"47. Rejeitando esses precedentes judiciais como a famosa decisão do Lord Coke no caso Dr. Bonham, em $1610{ }^{48}$ a supremacia parlamentar teve como corolário a irrevisibilidade da legislação parlamentar - a "onipotência" do controlar a "validade" da lei..$^{49}$

Se o modelo francês de impotência do judiciário encontra em Montesquieu seu mais autorizado teórico, embora não sem ambigüidades, John Locke é visto como tendo desempenhado papel similar na Inglaterra. direito (lei) positivo e a impotência judicial para

${ }^{46}$ Vide Judicial Review, supra nota 4, 36; J. H. MERRYMAN, supra nota 33, 16.

${ }^{47}$ A frase citada no texto tem uma literatura própria, discutindo a quem se deve a paternidade (De Lolme, Bagehot?). Vide, v.g. W. HOLDSWORTH, 12 A History of English Law, London, Methuen, 1938, reedição 1966, p. 344 n. 5; H. J. ABRAHAM, The Judicial Press, $2^{\mathrm{a}}$ ed., 1968, p. 295

${ }^{48}$ A decisão Bonham, como é muito conhecida, afirmava o poder que o judiciário tem de controlar a validade da legislação: "porque, quando um ato do parlamento é contra o direito e a razão comum, ou incompatível, ou impossível de ser aplicada, o direito consuetudinário o controlará e o considerarão um ato nulo." 8 relatórios Coge 118; 77 Eng. Rep. 652. Para um comentário muito utilizado vide T. F. T. PLUCKNETT, "O caso Bonham e Revisão Judicial” 40 Harvard Law Rev. 30-70 (1926). Vide também Judicial Review, supra nota 4, 36-41.

${ }^{49} \mathrm{Em}$ uma passagem muito criticada por John Austin. Blackstone afirmava que o direito natural, sendo "superior em obrigação" ao direito positivo, "é obrigatório sobre todo o mundo, em todas as nações, e em todos os tempos: nebuma lei human as as as aças neste original", de forma que "[somos] obrigados a e toda sua auid " Vommentaries of the Laws transgredir a lei hon "Of in England, Introduçao, seç̧ão Segunda 'Or the 41,43); John AUSTIN, The Povince of Jurisprudence Detán Nicolson, 1954, p. 184-186). Todavia, Blackstone tamberm afirmou que o poder do Parlamento é "tão transcendental e absoluto, que ele não pode ser confinado...dentro de quaisquer fronteiras...ele tem autoridade soberana e incontrolável para fazer, confirmar, aumentar, restringir, abrogar, anular, repristinar e interpretar as leis concernentes a matérias de qualquer natureza eclesiásticas ou temporais, civis, militares, marítimas ou criminais: este sendo a sede em que esse poder absoluto e despótico, que há de residir em qualquer governo, é posto pelas constituições deste reino...Pode, em suma, fazer tudo quanto não seja naturalmente impossível; e por isso alguns não têm escrúpulos em exercer este poder, através de uma imagem excessivamente ousada como e a onipotência do parlamento. Na verdade, o que o Parlamento faz, nenhuma força no mundo pode desfazer Consequentemente, enquanto a Constituição inglesa subsistir, ousaremos afirmar que o poder do parladefaze. messibilidade de os juízes a Inroduça, seça 3" " afastarem as leis do " "qu "posa "têm liberdade para rejeitá-las", conheço poder", diz ele, "que "possa obstar "tais leis, e sustentar que os jưzes "thm liojo colocaria o poder judicial acima da legislatura, o que seria a subversáo de qualquer goveno. Como Pound observou acertadamente, quando Blackstone "aplica [esta teoria do direito natural] à legislaçăo, ele se retra". "Common Law and Legislation", 21 Harv. L.Rev. 338, p. 392 (1908)

Revista da Faculdade de Direito da UFRGS, v. 20, Outubro/2001 
Embora esteja freqüentemente associado com a histórica doutrina da separação dos poderes, Locke de fato não via o judiciário como um "ramo" ou "poder" separado. Em sua tricotomia, os dois poderes "derivados" ou "inferiores" eram o "executivo 50 " e o "federativo" 51 , enquanto o poder "supremo", o "legislativo, ${ }^{52}$ é magnificado como o "a alma que dá Forma, Vida, e Unidade à Commonwealth" ${ }^{53}$. Ainda que o "legislativo" de Locke estivesse constrangido a "revelar" e a "executar" as "eternas e imutáveis leis da natureza", descobertas mas não criadas pela razão $0^{54}$, ele não via o judiciário como o aplicador competente e privilegiado desses naturais limites legais da vontade legislativa ${ }^{55}$. A doutrina de Locke repercutiria e far-se-ia mais explícita através de Blackstone, quando o grande comentador rudemente rejeitou a revisão judicial, considerando-a como eqüivalendo a colocar "o poder judiciário acima do legislativo, o que seria a subversão de todo o governo". ${ }^{56}$

Diferentemente do que ocorre na França, não se trata de história passada para a Inglaterra. A supremacia parlamentar ainda é ali afirmada como um princípio básico: a Grundnorm ${ }^{57}$ da constituição não escrita daquele país. Nos últimos anos, porém, significativas brechas foram abertas nos sólidos princípios das tricentenárias muralhas. Mencionarei apenas

duas que se aplicam ao Reino Unido, e ao mesmo tempo a várias das demais nações da Europa Ocidental. Elas nos revelaram uma nova e única dimensão do extraordinário desenvolvimento e crescimento da revisão judicial na Europa, vale dizer, sua dimensão transnacional.

\section{Estaria a Inglaterra Abandonando Sua Grundnorm Lockeniana? A Lei Comum "Não poderia Ser Detida"}

A primeira "brecha na muralha" foi aberta pela Comunidade Européia. Como se sabe desde 1973 o Reino Unido tornou-se membro pleno da Comunidade Européia - o assim chamado Mercado Comum, de que ora participam dez países da Europa, mas que em breve tornar-se-ão treze, com uma população de cerca de 300 milhões de pessoas. Uma das características básicas da Comunidade é a de que ela se auto-outorgou poderes legislativos, em um largo espectro de áreas, especialmente na econômica, mas também no plano social. $\mathrm{O}$ direito comunitário, na sua maior parte promulgado pelo Conselho de Ministros da Comunidade Européia, com alguma participação da Comissão Comunitária e do Parlamento Europeu, provou ser um ordenamento de

so John LOCKE, The Second Treatise of Government, cap. XII, §§ 145, 149 et passim.

${ }^{51}$ The Second Treatise, cap. XII, §§ 145-148 et passim.

${ }^{52}$ The Second Treatise, 52, cap. XI, § 134, cap., 149, et passim.

${ }^{53}$ The Second Treatise, cap. XIX, § 212. Pode ser verdade, no entanto, que em razão do poder legislativo e mais geralmente, do "poder de governar", ter sido considerado por Locke como "a promulgação e a sanção de uma lei,

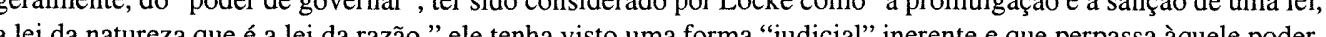
. in University Press, 1960, 96, 107; vide, v.g., The Second Treatise, cap. VII, \$§ 88-89, cap. XI, § 136.

${ }_{55}^{5}$ Vide, v.g., The Second treatise, cap. IX, \& 124.

${ }_{55}$ Vide v.g., The Second Treatise, cap. XI, \& 135 .

${ }^{56}$ Vide nota 49, supra.

${ }^{57}$ Vide v.g., G. WINTERTORN, "The British Grundnorm: Parlamentary Supremacy Re-examined" Law Quartely Review, 1976, 591-617.

Revista da Faculdade de Direito da UFRGS, v. 20, Outubro/2001 legislação transnacional em expansão, consistindo por enquanto, basicamente em milhares de "regulamentos" e "diretivas". 58

$\mathrm{Na}$ expressiva frase de Lord Denning, este corpo legislativo da comunidade penetrou no sistema legal britânico e no sistema dos outros nove Estados membros "como uma maré crescente, [que] corre pelos estuários e rios adentro [e que] não pode retroceder." ${ }^{59}$ A razão pela qual ele não pode ser contido decorre do princípio básico do direito comunitário que assegura a "aplicação direta" da lei da comunidade, como sendo automaticamente the law of the land de cada um dos Estados membros ${ }^{60}$. Nas palavras ainda de Lord Denning: "o Parlamento decretou que (a lei da Comunidade) é....parte de nosso direito."

Tal conseqüência é da própria natureza do direito Comunitário, porquanto, pelo menos como regra geral, ele deverá ser uniformemente aplicado em todos os Estados membros. Isso explica porque, desde 1964, consistente corrente jurisprudencial da Corte de Justiça
Européia - a Corte da Comunidade, com sede em Luxemburgo - estabeleceu que o direito da Comunidade não é somente o direito de todos os Estados membros, a ser diretamente aplicado por todas os tribunais nacionais, como também, e sobretudo, é a mais alta lei dos Estados membros, prevalecendo sobre a legislação nacional conflitante ${ }^{62}$. A legislação nacional, independente da data de sua promulgação, há de ser afastada pelos tribunais nacionais dos dez países, se considerada contrária à legislação da Comunidade ${ }^{63}$, e os problemas de interpretação se resolvem, em última instância e com efeito final, para todos os Estados membros, pela Corte Européia de Justiça. $^{64}$

Podemos verificar, assim, que uma nova e importante forma de revisão judicial da legislação penetrou nos "estuários e nos rios" da Inglaterra e também nos outros nove sistemas jurídicos europeus. É uma forma de revisão muito similar à decisão executiva americana da supremacia da legislação federal

58 Vide v.g. C. Sasse \& H. C. YOUROW \& E. STEIN, eds., COURTS AND FACE MARKETS, I, Oxford, 88 Vide v. C. Clarendon Press, 1982, Law and Institutions in Perspective, Indianapolis, Bobto, Luxemburgo, Office for Official Publications of the COMMUNITIES, 30 anos da

European Communities, 1983.

59 Vide
1226.

${ }^{\circ} \mathrm{O}$ princípio foi afirmado pela primeira vez na histórica decisão da Corte de Justiça Européia (CJE), van Gend en Loos v. Nederlandse Administrative Belastingen, Case 26/62 (1963) ECR 1. Vide v.g., L. N. BROWN N. F. G. JACOBS, The Court of Justice of the European Communities, $2^{a}$ ed., London, Sweet \& Maxwell, 1983, p. 162. ${ }_{61}$ Vide Comparative Const. Law, supra nota 45, p. 137. Vide também M. P. FURMSTON, R. KERRIDGE \& B. SUFRIN, eds. The Effect on English Domestic Law of Membership of the European Communities and of Ratification of the European Convention on Human Rights, The Hague, Nijhoff, 1983, 1-246.

${ }_{62}$ A primeira afirmação da preeminência da doutrina pode ser encontrada em outra histórica decisão da CJE, 22 A primeira afirnaça da pres) ECR 585. Sobre a gradual aceitação pela maioria da cortes nacionais da doutrina Costa v. ENEL, Caso 64 (19) "The Mighty Problem", supra nota 42, p. 424-426; R. KOVER, da suprenaia do dieto da Comuide Community Law, Luxembourg, 1982, 109 .

${ }^{63}$ Vide a decisão da CJE in Simmenthal, Case 106/77, (1978) ECR 629

${ }^{64}$ Vide v.g., L. N. BROWN \& F. G. JACOBS, supra nota 60, p. 281-285; decisão da CJE Da Costa en Schaake, Casos 18-30/62 (1963) ECR 31. Geralmente no papel da Corte de Justiça Européia vide M. CAPPELLETTI, M. SECCOMBE N J. WEILER, eds. Integration Through Law. Europe and the American Federal Experience, Vol. 1, Livro 2, Berlin \& New York, de Gruyter, 1986, publicação inédita.

Revista da Faculdade de Direito da UFRGS, v. 20, Outubro/2001 
sobre as leis estaduais conflitantes. Na verdade, não se trata de um controle de constitucionalidade da legislação, embora seja pelo menos um primeiro passo para o reconhecimento, mesmo na Inglaterra, de que o princípio histórico da absoluta supremacia da lei Parlamentar não mais prevalece inteiramente.

\section{VII.A 'Justiça Transnacional"da Corte Européia dos Direitos Humanos}

Um segundo desenvolvimento dessas idéias diz mais respeito a nossa preocupação inicial, ou seja, à revisão da constitucionalidade da legislação e mais especialmente à revisão judicial, como instrumento de proteção dos direitos humanos. Realmente, há poucos anos, o desenvolvimento do que eu discutirei agora motivou o ilustre constitucionalista americano Charles Black - um anterior "conselheiro", segundo me foi dito, "do Papa João XXIII" - a sustentar que a Inglaterra, ao contrário da opinião geralmente aceita, realmente já tinha direitos fundamentais escritos e obrigatórios..$^{65}$ Esse segundo episódio, materializou-se especialmente quando o Reino Unido, membro

signatário da Convenção dos Direitos Humanos desde 1951, aceitou em 1966 a cláusula opcional do artigo 25 desta Convenção. ${ }^{66}$ Esta cláusula estabelece uma forma de Verfassungsbeschwerde transnacional, que estende a todos os cidadãos, após esgotados os remédios nacionais, o direito de apresentarem suas reivindicações perante $o$ aparelho judiciário da Convenção em Strasbourg contra qualquer sorte de ato administrativo, incluindo legislação, violador de seus direitos protegidos pela Convenção. Relembro que a Convenção é um abrangente bill of rights transnacional, ao qual aderiram, com a única exceção da Finlândia, todos os países da Europa Ocidental - vinte e uma nações, perfazendo uma população de mais de 350 milhões de pessoas. ${ }^{67}$

Dessa forma, um bill of rights transnacional tornou-se obrigatório para a Inglaterra, entre outras nações, e é imposto por um magistrado transnacional a quem os cidadãos britânicos têm acesso. Nesse contexto, basta um pequeno passo para aceitarse a idéia de que a Convenção faz parte do direito da Inglaterra, impondo-se de forma obrigatória para o Parlamento Britânico, e que os tribunais ingleses devem aplicá-lo, salvo se quiserem que seus julgamentos sejam submetidos à apreciação dos julgadores transnacionais em

${ }_{65}^{65}$ C. L. BLACK Jr. "Is There Already a British Bill of Rights?", 89 Law Quaterly Rev. 173 (1973). ${ }^{66} \mathrm{~A}$ aceitação, primeiro limitada a um período 3 anos, foi desde então regularmente renovada; a última ocorreu em 1981 por um período de cinco anos. Vide geralmente A. Z. DRZEMCZEWSKI, European Human Rights Convention in Domestic Law, Oxford, Clarendon Press, 1983, 177-187, 362-363. ${ }^{67}$ Para breves pesquisas vide v.g., Rosalyn HIGGINS, "The European Convention on Human Rights", in T.
MERON, ed. Human Rights in Internationa Law, II, Oxford, Clarendon Press, 1984, 495-549; A H. ROBERTSON, Human Rights in the World, $2^{\mathrm{a}}$ ed. New York St. Martin's Press. 1982, 80-117. A convenção foi ratificada pelo seguintes países (em parênteses está, primeiro, o ano da ratificação, e, segundo, o ano ininterrupta da cláusula opcional do art. 25: Áustria $(1958,1958)$; Bélggndo, 0 ano da aceitação, desde então Islândia (1953, 1955); Irlanda (1953, 1953); Itália (1955, 1973); Liemana $(1952,1955)$; Grécia $(1974,1985)$; (1953, 1958); Malta (1967); Holanda (1954, 1960); Noruega (1952, 1955); Portugal (1978, 1978); Espanh (1978, 1981); Suécia $(1952,1952)$; Suíça $(1974,1974)$; Turquia $(1954)$ e Inglaterra $(1951,1966)$. Desses países somente três - Chipre, Malta e Turquia - ainda não aceitaram a cláusula opcional do art. 25. Para maiores nformaçoes relativamente também às ratificações do Protocolo da Convenção vide A. Z. Drzemczewski, supra nota 66, p. 362.

Revista da Faculdade de Direito da UFRGS, v. 20, Outubro/2001 marca (1953,1963); França (1974, 1981): República Fina (1953, 1958); Malta (1967);
Strasbourg ${ }^{68}$. Se os britânicos estão prontos para dar esse passo à frente e adotar assim um amplo e definido sistema de revisão judicial não é questão a ser discutir agora. Basta dizer que ações bem sucedidas têm sido submetidas à Convenção, por indivíduos, com bastante frequiência nos últimos anos, contra a legislação inglesa e outros atos administrativos ingleses, e em não poucos casos as condenações pela Comissão Européia e pela Corte da Direitos Humanos provocaram ressentimentos no Reino Unido, por terem atingido queridas tradições. Todavia, as autoridades inglesas, inclusive o Parlamento, geralmente demonstraram a determinação de se conformarem com as decisões finais da Corte Européia de Direitos Humanos. Assim sendo, de facto, a supremacia da constituição transnacional tem sido largamente confirmada na Europa Ocidental ${ }^{69}$.

A Grã-Bretanha em particular, embora

ostensivamente mantendo suas tradições de rejeitar a revisão judicial da legislação, percorreu própria tradição - uma lockeniana e blackstoniana tradição, somos tentados a dizer - da doutrina da incontrolabilidade judicial da vontade legislativa ${ }^{70}$.

\section{Sobre o "Tormentoso Problema" da Legitimidade Democrática da Justiça Constitucional}

Vimos como a revisão judicial foi recentemente introduzida, ou teve seu papel grandemente expandido, num grande número de países. Realmente, nossa lista para ser um longo caminho para finalmente repudiar sua

${ }^{68}$ A respeito do impacto da Convenção Européia no Reino Unido vide A. Z. DRZEMCZEWSKI, supra nota 66, 177-187, com referência a um número de casos; M. P. FURMSTON, R. KERRIDGE \& B. E. SUFRIN, supra nota 61, 247-428.

${ }_{69}^{6}$ A respeito da autoridade e adequação com as decisões dos órgãos decisórios da Convenção Européia dos Direitos ${ }^{69}$ A respeito da autoridade e adequação com as decisões dos órgãos decisoorios da Convenção Européia dos Direitos
Humanos nos vários estados membros vide A. Z. DRZEMCZEWSKI, supra nota 66, p. 260-325. Com especial Humanos nos vários estados membros vide A. Z. DRZEMCZEWSKI, supra nota 66, p. 260-325. Com especial
atenção ao Reino Unido, vide os recentes comentários do Presidente do Law Commission of the European for atenção ao Reino Unido, vide os recentes comentários do Presidente do Law Commission of the European for
England and Wales, The Honourable Mr. Justice GIBSON, "Legal Procedure: Acess to Justice, 1883 to 1983", in 9 Dalhousie Law Journal" 3, $27-28$ (1984): O Reino Unido foi intimado por estar em falta com suas obrigações perante a Convenção Européia em inúmeros casos. O governo sem dúvida considerou esses acontecimentos surpreendentes e embaraçosos. Uma brecha foi estabelecida em um caso sobre o trabalho em loja que teve suas atividades encerradas numa de nossas estradas de ferro nacionalizadas, na qual os danos... e os custos...foram assegurados a três reclamantes. Houve casos...sobre imigração. Brechas também foram estabelecidas em petições individuais em outros contextos, como o uso de punição física numa escola sem o consentimento dos pais; a censura de cartas pelas autoridades carcerárias e a recusa de permissão de apenados procurarem aconselhamento legal, e o direito consuetudinário de desacato contra The Sunday Times Newspaper em suas investigaçose repor (a) For alga que as auso de vários métodos de interrogatório como permanecer em pe contra a parede, submissão a ruídos, privação do sono. A corte (Européia) sustentou que as técnicas não chegavam a ser torturas, mas eram desumanas e degradantes, conflitantes com o artigo III. A resposta do governo a estas e outras decisões foi a de suspender tais práticas ofensivas, muitas vezes antes da decisão da corte, e, quando necessário, de mudar a lei pertinente, como as regras da prisão. Não houve a intenção de desafiar a decisão da corte, embora nem todos concordem com a interpretação da Convenção pelas várias maiorias na Corte de Strasbourg. O Reino Unido poderia denunciar a Convenção dentro de seis meses conforme o artigo LXV...Não o fez e esta medida é bastante improvável.

${ }^{70}$ Vide "The Mighty Problem", supra nota 42, p. 424-430. 
completa deveria ser estendida a muitos outros países, incluindo a Suécia desde $1980^{71}$ e o Canadá especialmente desde sua nova "Carta de Direitos e Liberdades" constitucionais de $1982^{72}$. Deveria ter mencionado, além disso, que, mesmo em sua mais impressionante e historicamente sem precedente dimensão - a dimensão transnacional - o precedente europeu não se encontra mais só. A Convenção Americana sobre os Direitos Humanos, assinada em São José da Costa Rica, em 1969 tornou-se obrigatória para vários países desde 1978. Largamente modelada pela Convenção Européia, essa constituição transnacional levou à criação, em 1979, de uma Corte Inter-americana de Direitos Humanos, com sede em São José, abrindo-se talvez para futuros desdobramentos similares

aos já sensacionais de sua antecedente européia. ${ }^{73}$

Mas meu tempo está acabando, e desejo ainda discutir, posto que brevemente, a questão básica a respeito do significado e legitimidade da revisão constitucional à luz de seu tremendo desenvolvimento no mundo contemporâneo. ${ }^{74}$

Para muitas nações, como vimos, esse significado primeiramente foi o de uma reação contra passados abusos governamentais. Isso ficou sobretudo evidente em vários dos países mencionados e outros poderiam ser adicionados, da África, da Ásia e da América Latina. Inclusive nesses continentes particularmente na América Latina, onde alguns

${ }^{71}$ Vide o relatório Uppsala por Eivind Smith sobre os países escandinavos, supra nota 8; vide também, v.g., A BAYEFSKY, "Parliamentary Sovereignity and human Rights in Canada: The Promise of the Canadian Charter of Rights and Freedoms", Estudos Políticos, 1983, 239; J. B. D'ONORIO, "Le répatriement de la Constitution Canadienne", Revista internacional de direito comparado, 1983, 69 (especialmente p. 100-101 sobre as sérias 72 Vide

72 Vide o relatório Uppsala por John D. White sobre países da Common Law, supra nota 8; vide também, v.g., A BAYESKY, "The Parlamentary Sovereignty and Human Rights in Canada: The Promise of the Canadian Charter of Rights and Freedoms", Estudos Políticos, 1983, 229; J. B. D'ONORIO, "Le repatriement de la Constituition Canadienne", Revue internationale de droit comparé, 1983, 69 (esp., p. 100-101 sobre as sérias consequîncition "notwithstanding clause" da secção 33 da Carta).

${ }^{73} \mathrm{Um}$ sinal encorajador é a importante decisão tomada pela Corte Inter-Americana, sustentando, unanimemente, que uma lei da Costa Rica que requeria uma licença compulsória para jornalistas, viova e de expressão garantida pelo art. 13 da Convenção Americana dos Direitos Humb vave opinião (Corte Inter-Americana de Direitos Humanos, julgamento de 14 de BUERGENTHAL, R. NORRIS \& D. SHELTON, Protecting Humante, T. Publ., 1982; T. BUERGENTHAL "The Inter-Americas Syst supra nota 67, II, 439-493. Id. "The anerign Differences", 30 A3-493; Id., "The american and Europian Conventions on Human Rights: Similarities and States (OAS)", in K Vican Univ. Law Rev.155 (1981); H. GROSS ESPIELL, "The Organization of American States (OAS)", in K. Vasak, ed., The International Dimensions of Human Rights, II, Westport,Connecticut, Greenwood Press, 1982, 543-565; P. SIEGHART, The International Law of Human Rights, Ofxord, Clarendon Press, 1983, 401-414. Vide também Inter-American Commission on Human Rights, Ten Years of Activities 1971-1981, General Secretariat Organization of American States, Washington, D. C., 1982 (p. 11-13 discutindo a recente criação da Corte Inter-Americana de Direitos Humanos); Organization of american States. InterAmerican Court on Human Rights, Annual Report of the Inter-American Court of Human Rights, 1984, Washington, D. C., General Secretariat OAS, 1984 (um triste e impressionante documento do até agot, Waencorajador caso Schmidt de 1985 discutido previamente, Inter-American Court).

Limits: A Compcussão mais elaborada reporto-me a meus estudos, "The Law-Making Power of the Judge and its citada como "Law-Making Powe", "Nonaas University Law Rev., 15, especialmente $51-58$ (1981) [doravante Diver"]; "Nécesité et Légitimite", supsa nota 40, 475-493.

Revista da Faculdade de Direito da UFRGS, v. 20, Outubro/2001 aspectos do fenômeno da revisão judicial são mais antigos do que na Europa ${ }^{75}$ - estudo comparado demonstrou que a revisão judicial da constitucionalidade da legislação e do ato administrativo têm, ao menos, a potencialidade de agir como instrumento para proteger os indivíduos e as minorias, muito embora, verdade, a eficácia da revisão judicial no mundo em desenvolvimento tenha sido freqüentemente prejudicada pela insuficiente independência judiciária e pelo uso e abuso por parte do executivo do poder de suspender as garantias constitucionais $^{76}$. Mas, em nações como a Inglaterra, onde felizmente não houve ta herança de sério abuso governamental, a revisão judicial está emergindo indiretamente como um elemento dessa nova e fascinante tendência no direito, na política e nos direitos humanos: o transnacionalismo. O compartilhamento do poder vertical e o conseqüente pluralismo das fontes legais, um típico produto do transnacionalismo, tanto quanto do federalismo, trazem inevitavelmente a possibilidade de conflitos entre os vários níveis de poder, de leis e de direitos; e a revisão judicial é o instrumento natural para dirimir tais conflitos.

Verifica-se uma percepção generalizada o menos nos países ocidentais, de que, em nossa "era de leis" - como o Deão Calabresi denominou -77 é realmente uma salvaguarda valiosa o controle por um julgador independente, de um legislador cada vez mais

onipresente, cujo papel no Estado moderno cresceu em dimensões sem precedentes, mais ainda se considerarmos que esse controle constitui a necessária "coroação" da regra da lei. Na realidade, o legislador em sociedades democráticas é o representante e o responsável do povo, conquanto pertença à própria natureza da função judicial não serem os juízes facilmente responsabilizáveis. O paradoxo - de confiar a juizes não submetidos a controle externo a função de controlar políticos responsáveis revela-se, todavia, meramente aparente. Em nossas sociedades, os juízes deixam de ser controlados externamente somente no sentido de que eles não são e não deverão ser tidos como responsáveis perante os outros órgãos do poder ou face ao povo por suas decisões e filosofias individuais. Tal irresponsabilidade, todavia, só é sustada a curto e a médio prazo. Há muitas ligações que a longo prazo tornam os juízes conectados com seu tempo e com a sociedade. Esses laços podem ser reforçados pela maneira como são nomeados os membros do judiciário, quer neste país, ${ }^{78}$ quer na Europa, pela permanência dos juizes em seus cargos que, sem dúvida, deve ser longa o suficiente para lhes dar autonomia e segurança, estando, em regra, limitada a um certo número de anos, sem possibilidade de extensão. Também devese notar que a verdadeira natureza do processo judicial é altamente participativa, uma vez que o papel dos juizes baseia-se em casos da vida real e somente podem ser exercidos sobre e dentro de limites dos interesses e da

${ }^{75}$ Vide geralmente H. FIX-ZAMUDIO, Vienticincos años de Evolución de lá Justicia Constitucional 1940-1965, México, UNAM, 1968, esp. cap. 2.

${ }_{76}$ Vide os relatórios de Uppsala por Nwabuenze, supra nota 16, p. 18-23 e CARPIZO \& FIX, supra nota 16, §§ 61-69, 91, 95, 110 et passim. Professor Henkin aponta para o "que hoje pode parecer uma forte embora feliz omissão" da Constituição dos Estados Unidos que "não prevê sua suspensão, ou governo por decreto mesmo em omissão" da Constituição dos Estados Unidos que "não prevê sua suspensão, ou governo por decreto mesmo em 13,150 n. 31

77 Guido CALABRESI, A Common Law for the Age of Statutes, Cambridge, Mass., Harvard University Press, 1982

${ }^{78}$ Vide v.g., Robert DAHL, "Decisions-Making in a Democracy. The Supreme Court as a National PolicyMaker", 6 Journal of Public Law, 279, esp. p. 284-285 (1957).

Revista da Faculdade de Direito da UFRGS, v. 20, Outubro/2001 
controvérsia das partes. Nesse sentido, constata-se uma alta potencialidade de um contínuo contato do Judiciário com os reais problemas, desejos e aspirações ${ }^{79} \mathrm{da}$ sociedade. Uma sadia conseqüência de nossa liberdade de expressão está no fato de que os também juízes, dia após dia, estão sujeitos à crítica pública ${ }^{80}$. Quando falamos hoje na separação de poderes, certamente não queremos dizer "séparation" no sentido original francês; queremos dizer, isso sim, conexões recíprocas e controles mútuos. A irresponsabilidade judicial é uma irresponsabilidade politica e legal -, com importantes limitações no caso de abusos sérios. No entanto, não se trata de uma irresponsabilidade social $^{81}$. Abusos do tipo análogo aos dos juizes do ancien régime francês seriam dificilmente concebíveis em nossas sociedades, pois aqueles eram abusos de um corpus séparé, um grupo social separado do resto da sociedade.

O "tormentoso problema" da legitimidade da revisão judicial não pode ser resolvido por meio de soluções puramente abstratas e especulativas que sejam válidas para todo o tempo e lugar. Realmente, inexistem tais soluções universais; e certamente uma página de realística análise comparativa pode ser mais valiosa do que muitos livros acerca de especulações abstratas ${ }^{82}$. Se nossos juízes atuais fossem da espécie que prevaleceu na França pré-revolucionária, então é claro que dificilmente legitimar-se-ia a revisão judicial. Mas, em nosso mundo ocidental, em que os papéis dos órgãos políticos se expandiram de uma maneira inevitável em tantas áreas da vida, a investigação de um Judiciário mais "destacado" - embora não literalmente "separado" -, pode ser mais saudável. Valores mais duráveis podem ser

79 Vide "Law-Making Power",supra nota 74, espec. p. 42-46, 54-57. Mesmo quando sua profissão ou papel possa, de algum modo isolar os juizes da sociedade, sua atividade "traz os juízes à realidade, uma vez que são chamados para decidir casos envolvendo a vida das pessoas, fatos concretos e problemas da vida real". Id. p. 57. ${ }^{80} \mathrm{~A}$ crítica, naturalmente, é facilitada pelo fato de que, em nossas sociedades, os mais importantes julgamentos e suas motivações são publicadas; é particularmente facilitada naqueles países em que a dissensão e as opiniões concorrentes são também publicadas. Vide o estudo comparativo por K. H. NADELMANN, "The Judicial Dissent: Publiation v. Secrecy", 8 Am. J. Comp. Law 415 (1959).

${ }^{81}$ Vide M. CAPPELLETTI, "Who Watches the Watchmen. A Comparative Study on Judicial Responsability", 31, Am. Journal of Comparative Law 1 (1983).

31, Am. Journal of Comparative Law 1 (1983). ${ }^{82}$ Aplicando os ensinamentos do grande historiador-filósofo Vico, "verum factum", o comparativista "especula" acerca da significação dos fatos, tendências e desenvolvimentos, não de abstrações. Giambattista VICO, Principi di Scienza Nuova (1744). Tradução inglesa de T. G. BERGIN and M. H. FISCH, The New Science of Giambattista Vico, Ithaca, N. Y., Cornell University Press, 1948. Análise comparativa, naturalmente, não é só a comparação de leis contemporâneas mas também a análise de sua evolução e tendências. A História, em outras palavras, é um componente na essencial análise comparativa.

Revista da Faculdade de Direito da UFRGS, v. 20, Outubro/2001

mais bem preservados ${ }^{83}$; pessoas e grupos que seriam de outro modo marginalizados ou oprimidos, podem ser mais bem protegidos; e, mais genericamente, a justeza e a permanente representatividade do processo político mais bem asseguradas ${ }^{84}$. O princípio democrático requer que cada cidadão tenha uma "voz" no processo político e que seja possível à minoria de hoje tornar-se a maioria de amanhã. Se os direitos fundamentais, como as liberdades de expressão, de opinião e de associação, pudessem ser limitados pela maioria ocasional, sem o devido processo, o próprio princípio democrático estaria em perigo; e isso não é menos verdade para os "novos direitos" de natureza econômica e social, porque sua rationale é a de tornar efetiva a mais básica de todas as titulações democráticas - o direito de acesso ao sistema legal e político. ${ }^{85}$ Dessa maneira, a Justiça constitucional, longe de ser inerentemente antidemocrática e antimajoritária, emerge como um instrumento central para escudar os princípios democráticos e majoritários contra o risco de corrupção. Nosso ideal democrático - deixemos o ponto firmemente vincado -, por certo não é aquele em que a vontade majoritária esteja onipresente. Além do mais, nossa filosofia de vida não é a de que tudo possa ser objeto de barganha.

\section{IX.A Revolução Contemporâ- nea dos Direitos Humanos e sua Legitimidade - Vencendo o Tradicional Conflito entre o Direito Natural e o Positivo}

Resumo agora, de modo conclusivo, as duas mais importantes teses aqui tratadas. A primeira é que, desde a II Guerra Mundial, as sociedades ocidentais têm vivido de uma maneira que não hesito em caracterizar como

${ }^{83}$ Vide v. g., Alexander M. BICKEL, The Least Dangerous Branch, Indianápolis, Bobbs-Merril, 1962, 25-27 et passim. É freqüentemente dito que a moderna jurisdição constitucional, enquanto potencialmente um poderoso instrumento para a proteção de direitos e valores políticos tradicionais, não tem potencial para também ser ou se tornar um instrumento para a protec̃a e a implantaç̃o dos "novos" direitos sociais e econômicos. Porque estes dicios, diferent direitos, dferentem judicia (a) Maiores dificuldades são encontradas e maiores restrições são recomendáveis, quando as cortes, considerando a ilegitimidade da inação governamental, determinam ao governo fazer algo com todas as implicações economicas e outra daí decorrentes, do que quando simplesmente declaram a ilegitimidade de um ato governamental. Estudos comparativos demonstram, no entanto, que há muitas maneiras para as cortes intervirem mesmo nesta área mais difícil Um recente exemplo é fornecido pela Corte de Burger, certamente uma corte não atuante na esfera dos direitos sócio- econômicos. Vide Ake v. Oklahoma, 105 S. Ct. 1087 (1985), na qual somente um juiz dissentiu e a corte manteve o ponto de vista de que os Estados devem providenciar para que os acusados indigentes disponham de assistência psicológica ao prepararem sua defesa por insanidade, caso a sanịdade do acusado, no tempo do crime, possa vir a ser um importante fator para o julgamento.

${ }^{84}$ Vide v.g., Martin SAPHIRO, Freedom of Speech: The Supreme Court and Judicial Review, Englewood Cliffs, N. J. Prentic Hall, 1966, 37 t t passim, J. H. ELY Democracy and Distrust, Cambridge, Mass. Harvard University . J. Prs, 1980. A tese centa do le Press, (a) justo e transparente para a correção de "malfuntions" deste processo que iria enfraquecer a efetiva participação das minorias.

"s Vide M. CAPPELLETTI \& B. GARTH, "Access to Justice: The Worldwide Movement to Make Right effective", in M. CAPPELLETTI \& B. GARTH, eds. Access to Justice Vol. I: A World Survey, Milan \& Alphen aan den Rijn, Giuffrè \& Sijhoff and Noordehoff, 3-124. Vide geralmente M. CAPPELLETTI, ed., Access to Justice and the Welfare State, Alphen aan den Rijn \& Bruxelles, Sijhoff \& Bruylant, 1981.

Revista da Faculdade de Direito da UFRGS, v. 20, Outubro/2001 
uma revolução constitucional de direitos humanos. Realmente, em alguns momentos houve sinais de que essa tendência iria além do mundo ocidental: menciono apenas Declaração Universal dos Direitos Humanos de 1948 e os Convênios Internacionais de 1966 em vigor desde $1976^{86}$. Mas, infelizmente, esses documentos não foram acompanhados po processos legais e por instituições fortes o bastante, para concederem o necessário grau de efetividade às regras neles incorporadas. ${ }^{87}$ $\mathrm{E}$, mesmo essas tentativas embrionárias tal como permanecem, são significativas, pois testemunham uma aspiração universal, embor ainda largamente irrealizada.

Claro que nosso ceticismo, assim como as várias e fracassadas implementações e as violações gerais da filosofia dos direitos

humanos, pode, muitas vezes, encobrir arter humanístico de nosso tempo, e, na verdade, muitos acontecimentos podem obscurecê-lo e até mesmo negá-lo ridicularizá-lo. Rejeito, todavia o ceticismo não construtivo e excessivo, assim como o seu irmão gêmeo, o nihilismo - essas duas recorrentes doenças do narcisismo intelectual. Estamos convencidos, assim como o grande filósofo do "ceticismo moderado", David Hume, de que o ceticismo excessivo não pode resistir ao teste da "ação" e da realidade da "vida comum" 88 . Essa realidade demonstra que, do mesmo modo como afirma e demonstra amplamente o professor Henkin, há uma "explosão" de direitos humanos nas "democracias libertárias" de nosso mundo contemporâneo ${ }^{89}$ Essa explosão tem sido caracterizada por uma preocupação sem

${ }^{86}$ Vide, v. g., L. HENKIN, ed., The International bill of rights. The Convenant on Civil and political rights, New York, Columbia University Press, 1981; id., supra nota 19, p. 89-101. Outro importante desenvolvimento de nosso tempo, o impulso contra o colonialismo, que trouxe à luz dezenas de novas nações nos anos após a II Guerra Mundial pode ser visto como uma expressão da tendência mencionada no texto. Como disse o Professor Henkin foi este impulso que "revelou uma quantidade de novos Estados e governos que procuraram nos direitos humanos para alcançar a "autonomia" e a eliminação do racismo." Id. supra, nota 19, p. 18. ${ }^{87}$ Cfe. id., supra nota 19, p. 101-102, 107-113; L. HENKIN, "The International Human Rights as 'Rights' in 257-280; L. B. SOHN, "Human Rights: Their Implementation and Supervision by the United Nations", in Meron, supra nota 67, II, 369-401.

${ }^{88}$ Hume, in Enquiry Concerning Human Understanding, Setor XII, Part. I (in Enquiries Concerning the Human Understanding and Concerning the Principles of Morals por DAVID HUME reimpressão da Edição Póstuma de 1777, L. A. Selby-Bigge editor, $2^{\mathrm{a}}$ ed., Ofxord Clarendon Press, 1902, reimpressão 1963, p. 149). Embora ensinando que o conhecimento humano é limitado à experiência das idéias e impressões, e excluindo a possibilidade de qualquer verificação de suas verdades, Hume condenou severamente o que foi chamado de
ceticismo "excessivo" ou "pirrônico": ceticismo "excessivo" ou "pirrônico":

Porque aqui está a principal e mais confusa objeção do ceticismo excessivo, donde nada de bom e durável pode advir....[O Ceticismo pirrônico] precisa reconhecer...que toda a vida humana deve perecer, onde seus princípios firme e universalmente prevalecem...[Todavia] a natureza, em princípio, é muito forte...[o] primeiro e mais trivial acontecimento da vida esfumaçará todas as dúvidas [pirrônicas]...Quando [um cético excessivo] acorda de seus sonhos, ele será o primeiro a juntar-se no riso de si mesmo e a confessar que todas as suas objeç̃es sã da de divertimentos e não podem ter outra tendência do que mostrar a caricata condicão humana, que precisa aros raciocinar e acreditar; embora as pessoas disso não sejam capazes, apesar de suas mais diligentes in

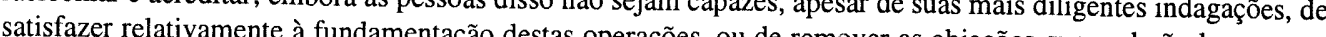
contra elas (Ibidem Setor XII, Parte II destas operaço Setor XII, Parte II, p. 158-160).

intelectul teriam quantos textos legais contemporâneos mudariam seu tema e tom e quanta energia e talento ${ }_{89}^{\text {intelectual teriam melhor uso se os ensinamentos de Hume tivessem sido assimilados. }}$

${ }^{89}$ L. HENKIN, supra nota 19, espec. p. 43-55, 156-161.

Revista da Faculdade de Direito da UFRGS, v. 20, Outubro/2001 precedentes com a criação de instrumento efetivos, nacionais e transnacionais - senão mesmo universais, para proteger os direitos básicos de pessoas e grupos - incluindo os pobres, as minorias raciais e religiosas, os jovens e os velhos, as mulheres e, mais amplamente, aqueles tradicionalmente privados de justo e igual acesso à justiça. Não reconhecer a importância histórica e o caráter desse crescente desenvolvimento implica permanecer surdo e cego à talvez mais espantosa tendência de transformação social que jamais ocorreu na história da humanidade. ${ }^{90}$

Isso está longe de ser uma rósea visão de nossa época. Em verdade, a explosão dos direitos humanos não passa de uma tentativa de dar resposta a problemas que, mais do que nunca, como disse no começo desta palestra, estão pondo em perigo a sobrevivência da civilização humana - os problemas da opressão, da pobreza e da guerra. Só o futuro dirá se esta

tentativa falhará ou terá sucesso. Mas parece claro para mim que, se for exitosa, os direitos nacionais e transnacionais e suas imposições judiciais terão uma boa parte do mérito. Torno bem clara a afirmação de que não vejo futuro para a humanidade, a não ser que uma renovada filosofia de tolerância e de mútuo respeito, num sentido real, ou seja, uma filosofia dos direitos humanos, capacite-nos a fazer uso decente do tremendo poder material que adquirimos.

A expansão sem precedentes do controle judicial dos órgãos políticos não é uma faceta secundária da revolução desses direitos humanos. Parece comprovar meu ponto de vista o próprio fato de que, até a época que se seguiu à II Guerra Mundial, a revisão judicial neste país, enquanto desempenhando um papel importante na formação de "uma mais perfeita União", não teve um papel adequado como instrumento para a perfeição dos direitos civis ${ }^{11}$. Somente em nossa época o momento é propício, para o que eu insisto em chamar de nossa revolução de

${ }^{90} \mathrm{~A}$ documentação de HENKIN focaliza os Estados Unidos sem a ele limitar-se, (para uma avaliação do desenvolvimento da Europa vide Comparative Constit. Law, supra nota 45, caps. 6-12). A "explosão dos direitos" desde a II Guerra Mundial está descrita como "impressionante":

A $14^{a}$ Emenda foi mantida por ter incorporado e tornado aplicável aos Estados as principais provisões do "Bill of Rights" - liberdade de expressão, de imprensa, de reunião, de religião, de segurança pessoal e de domicílio, Rights" - liberdade de expressão, de inim

salvaguarda para os acusados de crime...
Ainda mais impressionante foi a expansão de nossos direitos do século XVII em concep̧̧ão e conteúdo. Abrimos Ainda mais impressionante foi a expansão de nossos direitos do século XVII em concepção e conteúdo. Abrimos
nossa Constituição a cada homem e mulher, ao menor e ao pior deles. Nós a abrimos também a novos direitos e nossa Constituição a cada homem e mulher, ao menor e ao pior deles. Nós a abrimos também a novos direitos e à expansão da concep̧̧ão de velhos direitos...Nós salvaguardamos não apenas a liberdade política mas também, em princípio, a liberdade social, sexual, e outras liberdades pessoais, privacidade, autonomia, ...Todas as classificações raciais são suspeitas e prontamente verificadas... Houve uma fundamental e, creio eu, uma irresistível transformação no status da mulher...Os pobres também tiveram direitos à igual proteção, e o Estado não pode ofertar direitos importantes - um recurso criminal, um divórcio - mediante paga, sem torná-los disponíveis àqueles que não os podem pagar...Outras categorias, outrora fechadas, foram abertas: prisioneiros agora têm direitos, assim coms
funcionários militares, pacientes mentais, alunos nas escolas, e crianças independentemente de seus pais.

As cortes também descobrem novos direitos, por exemplo, o direito de viajar ao exterior bem como inter-Estados. (Elas) deschriram um área de autonomi fundamental, individu (chmada "privacide"), invaño

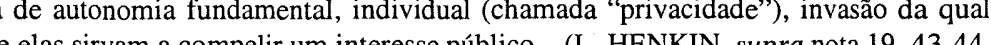
será.

${ }^{91}$ O fato inegável é que a revisão judicial na América desempenhou um papel modesto, algumas vezes até mesmo um papel negativo na proteção das liberdades civis, até poucas décadas atrás, seguidamente indigitada como evidência de um déficit da própria instituição. Vide v.g., Peter Railton, "Judicial Review, Elites, and Liberal Democracy", in Nomos XXV: Liberal Democaracy, J. R. Pennock \& J. W. Chapman eds. New York, New York University Press, 1983, 153-180, e a literatura ali mencionada.

Revista da Faculdade de Direito da UFRGS, v. 20, Outubro/2001 
direitos civis. Disse um escritor que uma das "características" das pessoas humanas é que somente o perigo e o sofrimento as fazem sensívei à justiça, aos sentimentos e à pergunta do que seja bom ou mau-em suma, aos seus valores inerentes. As tensões e os perigos de nosso tempo são tão grandes e iminentes, que este sentimento de valo de algum modo será forçado a emergir-queira Deus não apenas no ocidente. $\mathrm{E}$, em nossa sociedade ocidental, opapel privilegiado, embora não exclusivo, dos juízes nacionais e transnacionais tem sido o de interpretarem e de harmonizarem esses valores inegociáveis.

Minha segunda tese é a de que esse pape judicial mostra-se legítimo. Certamente podemos dissentir, até mesmo lutar contra certas determinações ou tendências em matéria de decisão constitucional. Mesmo, assim, um século e meio de história continental está aí para demonstrar que a solução alternativa é ainda pior. Na ausência de um controle judicial, o poder político se expõe mais facilmente ao risco da perversão. O controle judicial, certamente nãoé um remédio infalível; como proteção de nossas liberdades, muitas vezes pode provar ser incapaz de resistirà tirania, comodemonstrado pela experiênci de muitas nações. Se esse não é uma barreira invencível, talvez, possa agir, pelo menos, como um aviso e uma advertência.

Semelhante desenvolvimento marca renascimento de um novo "direito natural"? Muito afimamisso. ${ }^{93}$ Eu iria além, para dizer que o moderno constitucionalismo, com seus ingredientes básicos - uma Constituição garantidora de liberdades civis e

${ }^{92}$ Luigi PIRANDELO, Six Characters in Search of an Author, Ato III

...nunca as pessoas pensam tanto e se tornam tão introspectivas quanto em momentos de sofrimento; uma vez que estão ansiosas para entender...se é justo ou injusto o que estão sofrendo. Por outro lado, quando estão alegres pressupõem a alegria como algo evidente e não a procuram analisar, como se a alegria fosse para elas um direito natural.

${ }_{93}$ Uma ilustração típica é dada pelas contribuições no volume Natural Law and Modern Society, Cleveland \&

New York, The World Publishing Co., 1962. Vide também, v.g., L. HENKIN, supra nota 19, p. 19. Cfe. R. A. DWORKIN, "Natural Law Revisted", 34 Univ. of Florida Law Rev. 165-188 (1982).

${ }_{94}$ V ORKIN, "N3( 1033 meus estudos "Judicial Review in Comparative Perspective", 53 Califormia Law Rev. 1017, p. 1017-1020, 1032 1033 (1970); "The Significance of Judicial Review of Legislation in the Contemporary World", in Ius Privatum Gentium, Festschrift für Max Rheinstein (E. von Caemmerer, S. Mentschikoff \& K. Zewiger eds.), Tübingen, Mohr, 1969, p. 155162. Vide também HENKIN, supra nota 19, p. 5-23, 148-152, especialmente p. 19-23.

${ }^{95}$ Vide Jean RIVERO, "Rapport de synthèse", in Cours Constitucionnelles, supra nota 7, 517, p. 525-526.

Revista da Faculdade de Direito da UFRGS, v. 20, Outubro/2001

\section{Da extinção da punibilidade pela união estável da vítima com terceiro}

\author{
Mey Fayet Gúnior
}

Professor de Direito Penal - Especialista em Direito Penal (PUC/RS) Mestre em Ciências Criminais (PUC/RS) - Doutorando em Direito (UNISINOS) - Advogado.
L'

em breve resenha, discutir a ampliação das hipóteses de extinção da punibilidade ${ }^{1}$, em determinados crimes de índole sexual, a partir da união estável da vítima com terceiro. Aplica-se, neste caso, a analogia tem à censurabilidade jurídico-penal determinados episódios ilícito-típicos que, do contrário, estariam sujeitos à imposição da sanctio juris criminal.

No plano legal, inicialmente, apenas o casamento da vítima com o agente possuía o condão de extinguir a punibilidade. ${ }^{2}$ Posteriormente, também o casamento da vítima com terceiro in bonam partem, a fim de permitir que se fur-
- a partir da inovação trazida pela Lei n. ${ }^{\circ} 6.416 /$ $77^{3}$ - passou a ter o poder de eliminar a punibilidade. Isto se consolidou na Reforma do Código Penal, em 1984, com “....ligeiro acréscimo, visto que passou a contemplar o requerimento da vítima para o prosseguimento do inquérito ou da ação penal, enquanto o estatuto anterior só previa a segunda hipótese". ${ }^{4}$ Nos dias que correm, portanto, são: duas as hipóteses legalmente previstas pelas quais o casamento da vítima poderá extinguir a punibilidade nos crimes contra os costumes (Título VI, Capítulos I, II e III, do Código Penal): o casamento com o próprio agente (art. 107, VII, CP) e o casamento com terceiro (art. 107, VIII, $C P)^{5}$
${ }^{1}$ Como se tem como cetto, o Estado, “...como titular exclusivo de la potestad de castigar, puede disponer de esta, mediante 'renuncia'

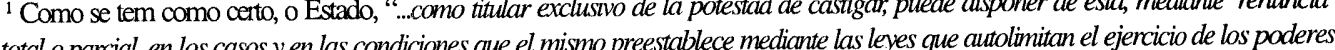
de soberaniac" (Vinenzo

${ }^{2}$ É o que nos informa Aníbal Bruno (Direito Penal: Parte geral, t. $3^{\circ}$. Rio de Janeiro : Forense, 1966, p. 229), quando ${ }^{2}$ E o que nos informa Anfibal Bruno (Direto Penal. Parte geral, t. 3 . Rio de Janeiro. Forense, 1966, p. 229), quando descreve: “...é preciso que o agente mesmo se case com a vítima, e não que esta contraia matrimônio com outrem. O que a lei exige para a extinção da punibilidade não é que a vitima se tenha refetio da desonra, mas sim que o próprio agente venha oferecer-lhe a reparação máxima do dano que causou, o que só pode fazer casando-se ele mesmo com ela." ${ }^{3}$ Como refere E. Magalhães Noronha (Direito Penal, v. 1. São Paulo : Saraiva, 1999, p. 378), “...anteriormente à vigência da Lei $n .6416$, o casamento da ofendida com terceiro não gerava efeitos, pois o Código Penal referia-se, expressamente, ao casamento do agente com aquela (art. 108, VIII, da redação primitiva). Foi acrescentado pela nova lei, entretanto, um novo inciso a este dispositivo, o IX (redação primitiva), que determina a extinção da punibilidade pelo casamento da ofendida com terceiro, nos crimes referidos no inc. VIII (redação primitiva), salvo se cometidos com violência ou grave ameaça e se ela não requerer o prosseguimento da ação penal no prazo de sessenta dias a contar da celebração. A reforma de 1984, sabiamente, manteve a inovacão introduzida pela mencionada Lei $n .6 .416$, agora pelo art. 107, VIII, fazendo um correto acréscimo: obsta também o prosseguimento de inquérito policial, enquanto a lei anterior referia-se apenas à açãa penal".

${ }_{4}$ Paúo José da Costa Júnior. Curso de Direito Penal: Parte geral, v. 1. São Paulo : Saraiva, 1991, p. 229.

${ }^{5}$ Luiz Régis Prado. Curso de Direito Penal Brasileiro: Parte geral. São Paulo : RT, 1999, p. 497. 